\title{
A comprehensive review on COVID-19 vaccines: development, effectiveness, adverse effects, distribution and challenges
}

\author{
Md. Mijanur Rahman' ${ }^{1}$ Md. Habib Ullah Masum ${ }^{1} \cdot$ Shah Wajed $^{1}$. \\ Asma Talukder ${ }^{2}$ iD
}

Received: 17 September 2021 / Accepted: 30 December 2021/Published online: 1 February 2022

(C) The Author(s), under exclusive licence to Indian Virological Society 2022

\begin{abstract}
The present SARS-CoV-2 induced COVID-19 pandemic is responsible for millions of deaths, illnesses, and economic loss worldwide. There are 21 COVID-19 vaccines from different platforms approved worldwide for emergency use until 13 August 2021. Later, BNT162b2 obtained full approval from the FDA. The efficacy of the leading vaccines such as BNT162b2, mRNA-1273, GamCovid-Vac, Ad26.COV2.S, ChAdOx1 nCoV-19, and BBIBP-CorV, against SARS-CoV-2 documented as $95 \%$, $94.1 \%, 91.6 \%, 67 \%, 70.4 \%$, and $78.1 \%$, respectively. Moreover, against the Delta variant of SARS-CoV-2, BNT162b2, ChAdOx1 nCoV-19, and BBV152 showed $88 \%, 70 \%$, and $65.2 \%$ efficacy, respectively. Apart from the common adverse effects such as fever, fatigue, headache, and pain in the injection site, Bell's palsy with BNT162b2, myocarditis and pericarditis with mRNA1273, and thrombosis with ChAdOx1 nCoV-19 have been reported though seemed not alarming. Furthermore, global production and distribution of vaccines should be ensured in an equal and justifiable way that the immunity and protection against the virus would be optimum and persistent.
\end{abstract}

Keywords COVID-19 vaccines · SARS-CoV-2 . Immunogenicity · Effectiveness · Adverse effects · Distribution

Asma Talukder

atalukder.bge@nstu.edu.bd

1 Department of Microbiology, Noakhali Science and Technology University, Noakhali 3814, Bangladesh

2 Department of Biotechnology and Genetic Engineering, Noakhali Science and Technology University, Noakhali 3814, Bangladesh

$\begin{array}{ll}\text { Abbreviations } & \\ \text { CoVs } & \text { Coronaviruses } \\ \text { SARS-CoV-2 } & \text { Severe Acute Respiratory Syndrome } \\ & \text { Coronavirus 2 } \\ \text { COVID-19 } & \text { Coronavirus Disease 2019 } \\ \text { WHO } & \text { World Health Organization } \\ \text { MERS-CoV } & \text { Middle East respiratory syndrome } \\ & \text { coronavirus } \\ \text { VLPs } & \text { Virus-like Particles } \\ \text { DNA } & \text { Deoxyribonucleic acid } \\ \text { RNA } & \text { Ribonucleic acid } \\ \text { mRNA } & \text { Messenger RNA } \\ \text { saRNA } & \text { Self-amplifying RNA } \\ \text { ADE } & \text { Antibody-dependent enhancement } \\ \text { ERD } & \text { Enhanced respiratory disease } \\ \text { CDC } & \text { Centers for Disease Control and } \\ & \text { Prevention } \\ \text { FDA } & \text { Food and Drug Administration } \\ \text { APC } & \text { Antigen presenting cell } \\ \text { PHE } & \text { Public Health England } \\ \text { TLR } & \text { Toll like receptor } \\ \text { RBD } & \text { Receptor binding domain } \\ \text { CHO } & \text { Chinese hamster ovary } \\ \text { WIBP } & \text { Wuhan Institute of Biological Products } \\ \text { AMC } & \text { Advance Market Commitment } \\ \text { GNI } & \text { Gross National Income } \\ \text { IDA } & \\ & \end{array}$




\section{Introduction}

Coronaviruses (CoVs) have enveloped positive-sense and single-stranded RNA as genetic material with a highly diverse nature. It causes enteric, hepatic, and neurological diseases in humans and animals [59, 101]. The severe acute respiratory syndrome coronavirus 2 (SARS-CoV-2), a novel betacoronavirus is responsible for the coronavirus disease 2019 (COVID-19), which was first found in Wuhan of China on December 2019 in a group of people connected to a seafood market [101]. On 11 March 2020, World Health Organization (WHO) categorized COVID-19 as a pandemic as it had already spread almost all over the world [68]. According to an estimation, until 25 August 2021, around 214,126,106 cases and 4,468,112 deaths had been reported globally where the virus was found and played a devastating role incessantly [144].

Moreover, SARS-CoV found in 2002-2003, and Middle East respiratory syndrome coronavirus (MERS-CoV) in 2012 are two other coronaviruses that cause epidemics, including severe respiratory illness along with deaths in humans since 2000 [68]. Although some attempts have been made, there is no commercially available vaccine for SARS and MERS. Several reasons were responsible for this no commercial production of SARS and MERS vaccines, such as lack of suitable animal models during pre-clinical experimentation and deficit in investment because it was limited in a small geographical area compared to other infectious diseases such as influenza, tuberculosis, and HIV [94]. The development of the COVID-19 vaccines in this dire and demanding situation is quite different from the traditional vaccine development approaches [51]. The publication of the first genome sequence of SARS-CoV-2 on 11 January 2020 contributed significantly to developing a vaccine against the disease with unprecedented speed and magnitude [69]. The vaccine development process typically takes several years, but it has been accelerated through concurrent preclinical and early phase 1 studies, strategic risk measures, and adaptive trial designs [53]. Starting clinical trials of different COVID-19 vaccines within six months and conditional approval in 10 months from the beginning is a recordbreaking event in the vaccine development history. Several factors, including the rapid genome sequencing of the virus, sufficient funding with cutting-edge technology, global cooperation among the researchers, and priorities market demand, make it possible within this short period [71]. Because of its highly diverse nature, SARS-CoV-2 has been gone through many mutations [19], which result in the emergence of different variants of the virus. Consequently, the vaccine development procedure becomes more challenging to confirm adequate efficacy against those variants as mutations in the spike protein might affect the effectiveness of a vaccine [118]. Although the mutation rate of SARS-CoV-2 is half of influenza and one-quarter of $\mathrm{HIV}$, it results in the generation of many different variants, including Alpha (B.1.1.7), Beta (B.1.351), Gamma (P.1), Delta (B.1.617.2), Kappa (B.1.617.1), and Lambda (C.37) [140].

Considering the global interest and necessity of a comprehensive understanding of COVID-19 vaccines, we gathered all relevant information on the development, effectiveness, adverse effects, worldwide coverage, and challenges in this review to offer a better understanding of the progress of the vaccines, which will eventually contribute to halting the COVID-19 pandemic.

\section{Types of COVID-19 vaccines based on structure and mechanisms of action}

There are 138 vaccine candidates (among them, 21 are approved worldwide for emergency use) in the pipeline for COVID-19 as of 13 August 2021, and their mode of action relies on the immune response to its integral parts (DNA, RNA, or protein) $[34,53]$. The spike proteins (S protein) found on the surface of the SARS-CoV-2 is the central antigenic phenomenon by which the virus particle initiates its pathogenesis [55]. Until 13 August 2021, there are mainly five types of vaccine candidate developed and being used for vaccination, including the whole virus (live attenuated and inactivated), viral vector (replicating and non-replicating), protein subunit, nucleic acid (DNA and RNA), and virus-like particles (VLPs) vaccines (Table 1; Fig. 1) $[34,80,90]$.

\section{Whole virus vaccines}

Whole virus vaccines are weakened or inactivated forms of the specific viruses that trigger the host's protective immunity without causing disease. There are two types of whole virus vaccines such as live attenuated and inactivated vaccines. In the case of COVID-19, a weakened form of SARS-CoV-2 is used in live attenuated vaccines, which does not cause illness but replicates like the original SARSCoV-2. Additionally, in inactivated vaccines, modified or inactivated (by heat, chemical, or radiation treatment) SARS-CoV-2 is used, which genetic materials are noninfectious and non-replicating but can trigger an immune response. Both live attenuated and inactivated vaccines contain the whole or part of the SARS-CoV-2, but they could begin different types of immune responses [55]. Live attenuated vaccines can stimulate both cellular and humoral responses. In contrast, inactivated vaccines can only stimulate humoral response to the SARS-CoV-2 [55]. 
Table 1 Immunological significances of all vaccine candidates against SARS-CoV-2

\begin{tabular}{|c|c|c|c|c|c|c|c|}
\hline \multirow{2}{*}{$\begin{array}{l}\text { Vaccine } \\
\text { platform }\end{array}$} & \multirow{2}{*}{$\begin{array}{l}\text { Type of } \\
\text { antigen }\end{array}$} & \multirow{2}{*}{$\begin{array}{l}\text { Type of } \\
\text { immune } \\
\text { response }\end{array}$} & \multirow{2}{*}{$\begin{array}{l}\text { Neutralizing } \\
\text { antibody } \\
\text { response }\end{array}$} & \multicolumn{2}{|l|}{$\mathrm{T}$ cell response } & \multirow{2}{*}{$\begin{array}{l}\text { Immunogenicity } \\
\text { and required dose } \\
\text { (s) }\end{array}$} & \multirow[t]{2}{*}{ References } \\
\hline & & & & $\begin{array}{l}\mathrm{CD} 4+\mathrm{Th} \\
\text { cell }\end{array}$ & $\mathrm{CD} 8+\mathrm{T}$ cell & & \\
\hline Inactivated & $\begin{array}{l}\text { Inactivated } \\
\text { SARS- } \\
\text { CoV-2 }\end{array}$ & $\begin{array}{l}\text { Antibody } \\
\text { and/or cell } \\
\text { mediate } \\
\text { response }\end{array}$ & $\begin{array}{l}\text { Strong } \\
\text { response }\end{array}$ & $\begin{array}{l}\text { Th1 cell or } \\
\text { Th2 cell } \\
\text { depending } \\
\text { on adjuvant }\end{array}$ & Weak response & $\begin{array}{l}\text { Weak; requires } \\
\text { two or more } \\
\text { doses }\end{array}$ & {$[52,64]$} \\
\hline $\begin{array}{l}\text { Live } \\
\text { attenuated }\end{array}$ & $\begin{array}{l}\text { Weakened } \\
\text { SARS- } \\
\text { CoV-2 }\end{array}$ & $\begin{array}{l}\text { Antibody } \\
\text { and/or cell } \\
\text { mediate } \\
\text { response }\end{array}$ & $\begin{array}{l}\text { Strong } \\
\text { response }\end{array}$ & Th1 cell & Strong response & $\begin{array}{l}\text { Strong; requires a } \\
\text { single dose }\end{array}$ & {$[52,64]$} \\
\hline $\begin{array}{l}\text { Protein } \\
\text { Subunit }\end{array}$ & $\begin{array}{l}\text { SARS- } \\
\text { CoV-2 } \\
\text { spike } \\
\text { protein }\end{array}$ & $\begin{array}{l}\text { Antibody } \\
\text { and/or cell } \\
\text { mediate } \\
\text { response }\end{array}$ & $\begin{array}{l}\text { Strong } \\
\text { response }\end{array}$ & $\begin{array}{l}\text { Th1 cell or } \\
\text { Th2 cell } \\
\text { depending } \\
\text { on adjuvant }\end{array}$ & Weak response & $\begin{array}{l}\text { Weak; requires } \\
\text { two or more } \\
\text { doses }\end{array}$ & {$[52,64]$} \\
\hline $\begin{array}{l}\text { Virus-like } \\
\text { particles } \\
\text { (VLPs) }\end{array}$ & $\begin{array}{l}\text { Multiple } \\
\text { proteins } \\
\text { of SARS- } \\
\text { CoV-2 }\end{array}$ & $\begin{array}{l}\text { Antibody } \\
\text { mediate } \\
\text { response }\end{array}$ & $\begin{array}{l}\text { Strong } \\
\text { response }\end{array}$ & $\begin{array}{l}\text { Th1 cell or } \\
\text { Th2 cell } \\
\text { depending } \\
\text { on adjuvant }\end{array}$ & Weak response & $\begin{array}{l}\text { Weak; two or } \\
\text { more doses }\end{array}$ & {$[52,64]$} \\
\hline Viral vector & $\begin{array}{l}\text { Nucleic } \\
\text { acid of } \\
\text { SARS- } \\
\text { CoV-2 }\end{array}$ & $\begin{array}{l}\text { Antibody } \\
\text { and/or cell } \\
\text { mediate } \\
\text { response }\end{array}$ & $\begin{array}{l}\text { Depends on } \\
\text { pre- existing } \\
\text { anti-vector } \\
\text { immunity }\end{array}$ & Th1 cell & $\begin{array}{l}\text { Strong/weak response } \\
\text { depends on spike protein } \\
\text { vaccines (replicating and } \\
\text { non-replicating }\end{array}$ & $\begin{array}{l}\text { Strong, weak or } \\
\text { moderate; } \\
\text { requires two or } \\
\text { more doses }\end{array}$ & {$[52,64]$} \\
\hline DNA & $\begin{array}{l}\text { Nucleic } \\
\text { acid of } \\
\text { SARS- } \\
\text { CoV-2 }\end{array}$ & $\begin{array}{l}\text { Antibody } \\
\text { and/or cell } \\
\text { mediate } \\
\text { response }\end{array}$ & $\begin{array}{l}\text { Depends on } \\
\text { pre- existing } \\
\text { anti-vector } \\
\text { immunity }\end{array}$ & Th1 cell & Moderate response & $\begin{array}{l}\text { Weak; requires } \\
\text { two or more } \\
\text { doses }\end{array}$ & {$[52,64]$} \\
\hline RNA & $\begin{array}{l}\text { Nucleic } \\
\text { acid of } \\
\text { SARS- } \\
\text { CoV-2 }\end{array}$ & $\begin{array}{l}\text { Antibody } \\
\text { and/or cell } \\
\text { mediate } \\
\text { response }\end{array}$ & $\begin{array}{l}\text { Depends on } \\
\text { pre- existing } \\
\text { anti-vector } \\
\text { Immunity }\end{array}$ & $\begin{array}{l}\text { Th1 cell or } \\
\text { Th2 cell } \\
\text { depending } \\
\text { on adjuvant }\end{array}$ & $\begin{array}{l}\text { Strong/weak response } \\
\text { depends on the choice of } \\
\text { adjuvant and formulation }\end{array}$ & $\begin{array}{l}\text { Strong, weak or } \\
\text { moderate; } \\
\text { requires two or } \\
\text { more doses }\end{array}$ & {$[52,64]$} \\
\hline
\end{tabular}

There are eight COVID-19 vaccine candidates have been approved for emergency use in different countries and 12 candidates in the clinical evaluation stage, which are developed using inactivated vaccine platform until 13 August 2021 [34]. The approved vaccines are BBIBP-CorV (59 countries), Sinopharm-Wuhan (China), CoronaVac (39 countries), BBV152 (9 countries), CoviVac (Russia), QazCovid-in (Kazakhstan), KCONVAC (China), and COVIran Barekat (Iran). On the other hand, four live attenuated vaccine candidates are in clinical and preclinical trials worldwide $[34,80]$.

\section{Viral vector vaccines}

Viral vector vaccines use the host cells' translation machinery to produce antigens rather than having antigens by themselves. In this regard, modified viruses (vector) are used to deliver antigen encoding genes; in the case of SARS-CoV-2, the gene encodes the surface spike proteins found on the virus is delivered into human cells by other modified viruses. There are two main types of them, such as replicating and non-replicating viral vector vaccines. After cell entry, replicating viral vector vaccines produce whole viral particles in the host cells and generate the vaccine antigen (SARS-CoV-2 spike protein). On the contrary, non-replicating viral vector vaccines do not produce whole virus particles in the host cells but could generate only the vaccine antigen. Currently available viral vector vaccines for SARS-CoV-2 are mainly non-replicating types [56]. As of 13 August 2021, six non-replicating viral vector vaccines such as $\mathrm{Ad} 5-\mathrm{nCoV}$ (8 countries), Gam-Covid-Vac (70 countries), Sputnik Light (12 countries), Ad26.COV2.S (59 countries), ChAdOx1 nCoV-19 (121 countries), and Covishield (45 countries) are approved for emergency use around the world. Moreover, there are eight COVID-19 vaccines candidates are in the clinical, and 19 more are in the preclinical evaluation stage have also been developed using a non-replicating viral vector platform [81]. Conversely, only six COVID-19 replicating viral vector vaccine candidates are in the clinical, and 17 more are in the preclinical evaluation stage [81]. 


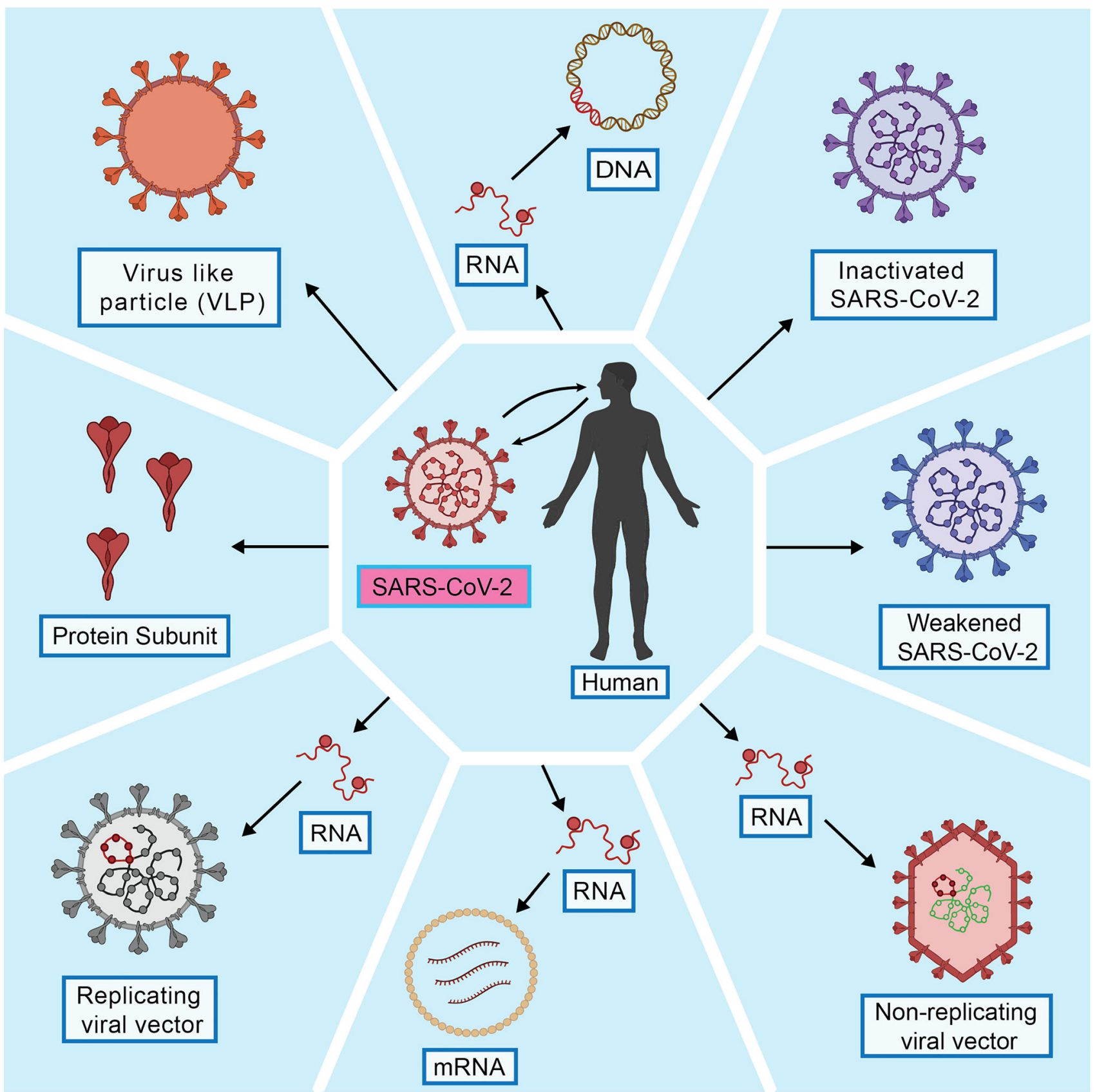

Fig. 1 Types of different COVID-19 vaccines and their manufacturing features. DNA vaccines manufacturing requires a plasmid DNA, but RNA vaccines are directly manufactured using lipid bilayer coatings; in both cases, the RNA of SARS-CoV-2 is the primarily targeted nucleic acid. For the inactivated and weakened vaccines, the original SARS-CoV-2 is inactivated or modified to retain antigenic properties but has no pathogenic phenomenon as the original SARS-

\section{Protein subunit vaccines}

The protein subunit vaccines contain purified antigenic parts of the desired virus rather than a whole virus to trigger an immune response. There are mainly two types of them such as polysaccharide and conjugate vaccines. The
CoV-2. The protein and virus-like particles vaccine manufacturing are similar as both target the surface proteins of the original SARS-CoV2 without considering its nucleic acid properties. In viral vector vaccines, modified viral particles (vectors) which can be replicating or non-replicating in nature are used to deliver the original SARS-CoV-2 RNA into the host (The figure has been drawn by conceiving ideas from Dai et al. [39])

polysaccharide vaccines contain polysaccharides from the viral cell wall, and the conjugate subunit vaccines tie on a polysaccharide chain with a carrier protein to boost the immune response [57]. Until 13 August 2021, there are four protein subunit vaccines such as ZF2001, EpiVacCorona (Russia and Turkmenistan), Abdala/ CIGB-66 
(Cuba), and MVC-COV1901 (Taiwan) have been approved globally for emergency use to prevent COVID-19, and there are also 78 candidates in the preclinical/ clinical trial stages [82].

\section{Nucleic acid vaccines}

Nucleic acid vaccines are manufactured utilizing the genetic material from a particular virus to provide immunity against the virus particles by encoding the viral antigen. The nucleic acid vaccine has two types such as DNA and RNA vaccines. In DNA-based vaccines, the DNA pieces encoding the viral antigen (specific antigen) are first incorporated into a bacterial plasmid and then injected into the host cell through electroporation, gene gun, or nanoparticle encapsulation to produce the desired viral antigen. In RNA vaccines, the viral antigen (specific antigen) encoding messenger RNA (mRNA) or self-amplifying RNA (saRNA) are used, which encode the viral antigen by using cellular machinery. The RNA (mRNA or saRNA) in an RNA vaccine can be injected by nanoparticles following encapsulation or delivered into cells using similar methods developed for DNA vaccines. Upon cell entry, the DNA or RNA begins encoding antigens in the cell cytoplasm, which are then shown on the cell surface, where they can be encountered by the immune cells and could trigger immune responses. These types of immune response generally are CD8 $+\mathrm{T}$ cell-mediated immunity and antibodymediated immunity by producing $\mathrm{B}$ cells and helper $\mathrm{T}$ cells [55]. Both the DNA and RNA vaccines can produce B and $\mathrm{T}$ cell-mediated immunity, though they have different conveniences. DNA vaccines have a risk of integrating the DNA with host DNA, whereas RNA vaccines have no such type of risk. Moreover, RNA vaccines require more cold storage temperature than DNA vaccines [55]. There are ten COVID-19 vaccine candidates in the clinical, and 11 candidates are in the preclinical evaluation stage as of 13 August 2021, which are developed using the DNA platform [83]. On the other hand, three COVID-19 vaccine candidates have been employed as an emergency vaccine, and 34 more vaccine candidates in the clinical and preclinical evaluation stage developed using the RNA platform [84]. BNT162b2 (97 countries), mRNA-1273 (65 countries), and TAK-919 (Japan) are mRNA based vaccines that have been using worldwide as authorized vaccines for COVID-19 [34].

\section{Virus-like particles (VLPs) vaccines}

The virus-like particles (VLPs) vaccines have protein multimers imitating the constituents of the original virus, which have no genetic material and thus are non-infectious. These synthetic particles can consolidate more than one type of protein responsible for forming protein chimeras known as cVLPs $[103,107]$. VLPs stimulate B and T cellmediated immune responses by antigen-presenting cells. The particles also produce CD8 $+\mathrm{T}$ cell responses, which facilitate the destruction of the viruses. The immune system recognizes VLPs as original viruses; thus, they can help boost immune responses $[60,103]$. The vaccines are mostly adjuvant-based because of the poor immunogenicity of the VLPs themselves [103, 153]. Until 13 August 2021, there are five COVID-19 vaccine candidates developed as VLPs in the clinical, and 17 more are in the preclinical evaluation stage [82, 85].

\section{A brief note on the principal approved vaccines against SARS-CoV-2 currently used worldwide}

A clear understanding of the immunological significances of the vaccines employed against newly emerged viruses is essentially required [39]. Recent studies also indicated that humoral and type 1 helper T cells (Th1) directed cellular immune response may have a crucial role in combating COVID-19 and elude vaccine-enhanced diseases [41, 70, 76, 91, 106, 116, 117].

$\mathrm{T}$ cells recognize viral antigens in the immunological process and respond to them by producing protective reactions and effector molecules. The cytokine interferon $\gamma$ is a molecule secreted by CD $4+$ and CD $8+T$ cells and their memory cells, measured in the ELISpot assay $[115,116,156]$. Moreover, a study suggested that the T cell-mediated immune responses can be lasted for at least six months after the vaccination [156]. Several published reports $[41,114,115]$ revealed strong evidence of $\mathrm{T}$ cell immune response sustainability, while the antibodies levels are declining, implying the persistence of the immunity [114]. The results from interim studies (phase 3 vaccine trials and previous phase 1 and 2 trials) claimed that the vaccines have good memory $\mathrm{T}$ cell responses, along with $\mathrm{B}$ cell antibody responses which will provide sound and possibly permanent immunity to SARS-CoV-2 [116]. The different COVID-19 vaccines generate various immunogenic responses and protective measures against the virus in the human body that are depicted in Fig. 2. Nevertheless, a paramount safety concern should have been considered on the antibody-dependent enhancement (ADE) and the enhanced respiratory disease (ERD) while developing a COVID-19 vaccine $[105,116]$. Insufficient concentration of neutralizing antibody produced by the vaccine can lead to the development of ADE disease in the host, where the antibodies are cross-reactive but their insufficient concentration can enhance secondary infections by other viruses $[64,105,116]$. 


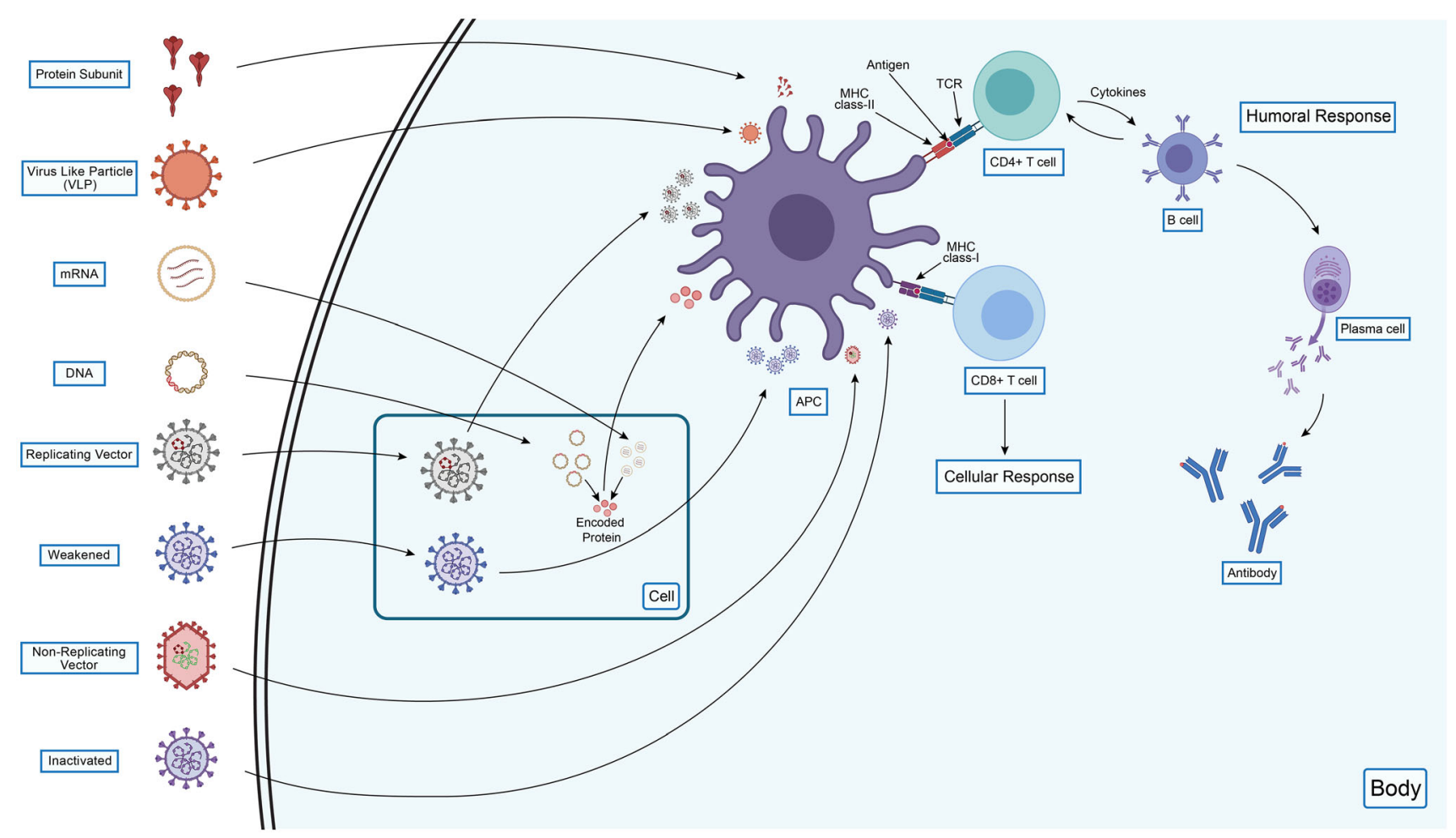

Fig. 2 An overview of COVID-19 vaccines' ways of generating immunity against the SARS-CoV-2 in humans. All the vaccines have similarities in activating immune responses upon infection, introducing APC, and further antigen processing. Following antigen presentation by MHC class-II and MHC class-I of APC to CD $4+\mathrm{T}$ cells and $\mathrm{CD} 8+\mathrm{T}$ cells, respectively, activation of these cells occurs, which later provides both humoral and cellular immune responses. $\mathrm{CD} 4+\mathrm{T}$ cells activation ensures $\mathrm{B}$ cells activation, subsequently activating plasma cells which provide antibodies as a means of the humoral response, while CD8 $+\mathrm{T}$ cells activation confirms cellular responses by providing active $\mathrm{CD} 8+\mathrm{T}$ cells or cytotoxic $\mathrm{T}$ cells. All the vaccines are encountered directly to the APC except the mRNA, DNA, replicating vector, and weakened vaccines. The mRNA and

Until 13 August 2021, at least 21 different types of vaccines have been approved for emergency use worldwide. These vaccines are BNT162b2, mRNA-1273, Ad26.COV2.S, ChAdOx1 nCoV-19, Gam-COVID-Vac, BBIBP-CorV, BBV152, Ad5-nCoV, CoronaVac, ZF2001, Sinopharm-Whuan, EpiVacCorona, CoviVac, Abdala/ CIGB-66, QazCovid-in, KCONVAC, MVC-COV1901, COVIran Barekat, TAK-919, and Sputnik Light [34, 122]. The World Health Organization (WHO) recommended six vaccines (BNT162b2, mRNA-1273, Ad26.COV2.S, ChAdOx1 nCoV-19, CoronaVac and BBIBP-CorV) for SARS$\mathrm{CoV}-2$, whereas CDC and FDA recognized three vaccines (BNT162b2, mRNA-1273, and Ad26.COV2.S) for emergency use (Table 2) [14, 129]. Remarkable progress has been made in the COVID-19 vaccines race while FDA provided full approval to the BNT162b2 vaccine on 23 August 2021 [130].
DNA vaccines encode the desired protein upon cell entry, and then APC process and present these proteins to the immunological cells. Both the replicating vector and weakened vaccines have replicating abilities; thus, they replicate upon cellular entry and are further encountered by the APC in the same manner. Despite having similarities among the vaccine immune responses, the protein subunit, virus-like particle, non-replicating vector, and inactivated vaccines do not provide cellular immune responses as they have no cellular entry like the rest of the vaccines. Thus, mRNA, DNA, replicating vector, and weakened vaccines provide both humoral and cellular responses as they have cellular entry before the APC recognition (The figure has been drawn by conceiving ideas from Nature [90])

\section{BNT162b2}

BNT162b2 has been developed and manufactured by BioNTech and Pfizer. It is also known as Pfizer-BioNTech/ COMIRNATY/ Tozinameran (INN). BNT162b2 is a nucleoside-modified mRNA vaccine that encodes for the viral spike glycoprotein of SARS-CoV-2, encapsulated in lipid nanoparticles $[15,70]$. After intramuscular injection, the lipid nanoparticles function as a barrier for mRNA degradation and allow the delivery of the mRNA into host cells. After cell entry, the mRNA encodes SARS-CoV-2 spike protein which is then expressed on the surface of the host antigen-presenting cells (APC). The expressed spike antigen on the surface of the host cells stimulates humoral (neutralizing antibody) and cellular immune responses against original SARS-CoV-2, thus preventing COVID-19 $[70,48]$. Sahin et al. [111] reported that the BNT162b2 elicited CD4 + and CD8 + T cells specific to SARS-CoV- 
Table 2 Globally approved vaccines for COVID-19 until 13 August 2021

\begin{tabular}{|c|c|c|c|c|c|c|}
\hline Vaccines & $\begin{array}{l}\text { Vaccine platform and } \\
\text { formulation techniques }\end{array}$ & $\begin{array}{l}\text { Target } \\
\text { antigen }\end{array}$ & Immunogenicity & Efficacy & $\begin{array}{l}\text { Dose and } \\
\text { time } \\
\text { interval }\end{array}$ & References \\
\hline BNT162b2 & $\begin{array}{l}\text { RNA, nucleoside } \\
\text { modification of SAS- } \\
\text { CoV-2 mRNA }\end{array}$ & $\begin{array}{l}\text { Spike } \\
\text { protein }\end{array}$ & $\begin{array}{l}\text { Both humoral } \\
\text { and cell } \\
\text { mediate } \\
\text { responses }\end{array}$ & $\begin{array}{l}\text { 95\%; } 88 \% \text { (against Delta } \\
\text { variant); 93\% (against } \\
\text { Alpha variant) }\end{array}$ & $\begin{array}{l}2 \text { doses, } \\
3 \text { weeks } \\
\text { apart }\end{array}$ & {$[75,97,111,139]$} \\
\hline mRNA-1273 & $\begin{array}{l}\text { RNA, encapsulation of } \\
\text { SAS-CoV-2 mRNA in } \\
\text { lipid nanoparticle } \\
\text { (LNP) }\end{array}$ & $\begin{array}{l}\text { Spike } \\
\text { protein }\end{array}$ & $\begin{array}{l}\text { Both humoral } \\
\text { and cell } \\
\text { mediate } \\
\text { responses }\end{array}$ & $\begin{array}{l}94.1 \% ; 100 \% \text { (against } \\
\text { Alpha variant); } 96.4 \% \\
\text { (against Beta variant) }\end{array}$ & $\begin{array}{l}2 \text { doses, } \\
4 \text { weeks } \\
\text { apart }\end{array}$ & {$[7,33,63,98]$} \\
\hline Ad26.COV2.S & $\begin{array}{l}\text { Non-replicating viral } \\
\text { vector, use recombinant } \\
\text { and replication } \\
\text { incompetent } \\
\text { Adenovirus type } 26 \\
\text { (Ad26) vector which } \\
\text { encodes the SAS-CoV- } \\
2 \text { spike (S) protein }\end{array}$ & $\begin{array}{l}\text { Spike } \\
\text { protein }\end{array}$ & $\begin{array}{l}\text { Both humoral } \\
\text { and cell } \\
\text { mediate } \\
\text { responses }\end{array}$ & $\begin{array}{l}67 \% \text { in phase } 3 \text { study; } \\
72 \% \text { in US; } 68.1 \% \text { in } \\
\text { Brazil study; } 64 \% \text { in } \\
\text { South Africa Study }\end{array}$ & Single dose & {$[66,92,108,128,139]$} \\
\hline $\begin{array}{l}\text { ChAdOx1 } \\
\text { nCoV-19 }\end{array}$ & $\begin{array}{l}\text { Non-replicating viral } \\
\text { vector, use recombinant } \\
\text { ChAdOx1 adenoviral } \\
\text { vector encoding the } \\
\text { spike }(S) \text { protein of the } \\
\text { SARS-CoV-2 }\end{array}$ & $\begin{array}{l}\text { Spike } \\
\text { protein }\end{array}$ & $\begin{array}{l}\text { Both humoral } \\
\text { and cell } \\
\text { mediate } \\
\text { responses }\end{array}$ & $\begin{array}{l}\text { 70.4\% (Interim); 79\% in } \\
\text { US phase } 3 \text { study; } \\
74.5 \% \text { (against Alpha } \\
\text { variant); 67\% (against } \\
\text { Delta Variant); In } \\
\text { Canada, 70\% (against } \\
\text { Delta variant), 72\% } \\
\text { (against Alpha variant), } \\
\text { 50\% (against both Beta } \\
\text { and Gamma variant) }\end{array}$ & $\begin{array}{l}2 \text { doses, } \\
12 \text { weeks } \\
\text { apart }\end{array}$ & {$[5,75,102,139]$} \\
\hline $\begin{array}{l}\text { Gam-COVID- } \\
\text { Vac }\end{array}$ & $\begin{array}{l}\text { Non-replicating viral } \\
\text { Vector, use human } \\
\text { Adenovirus type } 5 \\
\text { (Ad5) and Adenovirus } \\
\text { type } 26 \text { (Ad26) vector } \\
\text { encoding the spike } \\
\text { (S) protein of the } \\
\text { SARS-CoV-2 }\end{array}$ & $\begin{array}{l}\text { Spike } \\
\text { protein }\end{array}$ & $\begin{array}{l}\text { Both humoral } \\
\text { and cell- } \\
\text { mediated } \\
\text { responses }\end{array}$ & $91.6 \%$ & $\begin{array}{l}2 \text { doses, } \\
3 \text { weeks } \\
\text { apart }\end{array}$ & {$[73,74]$} \\
\hline BBIBP-CorV & $\begin{array}{l}\text { Inactivated SARS-CoV- } \\
2 \text {, in vitro production in } \\
\text { Vero cells }\end{array}$ & $\begin{array}{l}\text { Whole } \\
\text { virus }\end{array}$ & $\begin{array}{l}\text { Humoral } \\
\text { response }\end{array}$ & $\begin{array}{l}79.34 \% \text { in phase } 1 / 2 \\
\text { trial; } 78.1 \% \text { (WHO) }\end{array}$ & $\begin{array}{l}2 \text { doses, } \\
3 \text { weeks } \\
\text { apart }\end{array}$ & {$[139,147]$} \\
\hline BBV152 & $\begin{array}{l}\text { Inactivated SARS-CoV- } \\
2 \text {, in vitro production in } \\
\text { Vero cells }\end{array}$ & $\begin{array}{l}\text { Spike } \\
\text { protein }\end{array}$ & $\begin{array}{l}\text { Humoral } \\
\text { response }\end{array}$ & $\begin{array}{l}77.8 \% ; 65.2 \% \text { (against } \\
\text { Delta variant) }\end{array}$ & $\begin{array}{l}2 \text { doses, } \\
4 \text { weeks } \\
\text { apart }\end{array}$ & {$[45,46,148,149]$} \\
\hline Ad5-nCoV & $\begin{array}{l}\text { Non-replicating viral } \\
\text { Vector, use } \\
\text { recombinant } \\
\text { Adenovirus Type } 5 \\
\text { (Ad5) vector encoding } \\
\text { the spike (S) protein of } \\
\text { the SARS-CoV-2 }\end{array}$ & $\begin{array}{l}\text { Spike } \\
\text { protein }\end{array}$ & $\begin{array}{l}\text { Both humoral } \\
\text { and cell- } \\
\text { mediated } \\
\text { responses }\end{array}$ & $65.28 \%$ & Single dose & {$[118,154,155]$} \\
\hline CoronaVac & $\begin{array}{l}\text { Inactivated SARS-CoV- } \\
2 \text {, in vitro production in } \\
\text { Vero cells }\end{array}$ & $\begin{array}{l}\text { Whole } \\
\text { virus }\end{array}$ & $\begin{array}{l}\text { Mostly humoral } \\
\text { response, } \\
\text { aluminum } \\
\text { adjuvant } \\
\text { enhances } \\
\text { response more } \\
\text { robustly }\end{array}$ & $\begin{array}{l}51 \% \text { in Brazil, } 83.5 \% \text { in } \\
\text { Turkey; } 50 \% \text { (against } \\
\text { gamma variant) }\end{array}$ & $\begin{array}{l}2 \text { doses, } \\
2 \text { weeks } \\
\text { apart }\end{array}$ & {$[58,128,143,145,152]$} \\
\hline
\end{tabular}


Table 2 continued

\begin{tabular}{|c|c|c|c|c|c|c|}
\hline Vaccines & $\begin{array}{l}\text { Vaccine platform and } \\
\text { formulation techniques }\end{array}$ & $\begin{array}{l}\text { Target } \\
\text { antigen }\end{array}$ & Immunogenicity & Efficacy & $\begin{array}{l}\text { Dose and } \\
\text { time } \\
\text { interval }\end{array}$ & References \\
\hline ZF2001 & $\begin{array}{l}\text { Recombinant protein } \\
\text { subunit, use SARS- } \\
\text { CoV-2 spike (S) protein } \\
\text { receptor-binding } \\
\text { domain (RBD) encoded } \\
\text { in Chinese hamster } \\
\text { ovary (CHO) cells and } \\
\text { conjugated with } \\
\text { aluminum hydroxide }\end{array}$ & $\begin{array}{l}\text { Spike } \\
\text { protein- } \\
\text { RBD }\end{array}$ & $\begin{array}{l}\text { Humoral } \\
\text { responses }\end{array}$ & & $\begin{array}{l}3 \text { doses, } \\
4 \text { weeks } \\
\text { apart }\end{array}$ & {$[82,151]$} \\
\hline $\begin{array}{l}\text { Sinopharm- } \\
\text { Whuan }\end{array}$ & $\begin{array}{l}\text { Inactivated SARS-CoV- } \\
2 \text {, in vitro production in } \\
\text { Vero cells }\end{array}$ & $\begin{array}{l}\text { Whole } \\
\text { virus }\end{array}$ & $\begin{array}{l}\text { Humoral } \\
\text { responses }\end{array}$ & $72.51 \%$ & & [147] \\
\hline EpiVacCorona & $\begin{array}{l}\text { Protein subunit, peptide } \\
\text { antigens of SARS-CoV- } \\
2 \text { proteins, conjugated } \\
\text { to a carrier protein and } \\
\text { adsorbed on aluminum } \\
\text { hydroxide }\end{array}$ & & $\begin{array}{l}\text { Humoral } \\
\text { responses }\end{array}$ & & $\begin{array}{l}2 \text { doses, } \\
3 \text { weeks } \\
\text { apart }\end{array}$ & [99] \\
\hline CoviVac & & $\begin{array}{r}\text { Whole } \\
\text { virus }\end{array}$ & $\begin{array}{l}\text { Humoral } \\
\text { responses }\end{array}$ & & 2 doses & [99] \\
\hline
\end{tabular}

2 spike protein in the majority of vaccinated participants [70, 111]. In both subgroups (younger and older adults), 10-30 $\mu \mathrm{g}$ dose of the BNT162b2 can stimulate virus-neutralizing antibody production and antigen-binding $\mathrm{IgG}$ responses after administration of the second dose. In this instance, the neutralizing antibody titers were obtained before the first dose, 21 days after the first dose, and seven and 14 days apart from the second dose, in which the antibody titers were highest at seven and 14 days apart from the second dose of vaccination. Moreover, the younger had higher antigen-binding $\operatorname{IgG}$ and virus-neutralizing antibody responses than the older [70, 136].

BNT162b2 had an efficacy of 95\% against COVID-19 after a two-dose (30 $\mu \mathrm{g}$ per dose and 21 days apart) vaccination [97]. The vaccine efficacy was generally identical across subgroups with individuals of different ages, sex, race, ethnicity, obesity, and pre-existing conditions. For this instance, the efficacy was $93.7-100 \%$ in participants (age of $16-55,>55, \geq 65$, and $\geq 75$ years) who had no existing SARS-CoV-2 infection. Moreover, the efficacy also was similar in a separate analysis having participants with hypertension [70, 97]. Furthermore, the vaccine was $52.4 \%$ effective in preventing COVID-19 between two doses, but $90.5 \%$ effective within seven days interval of two-dose vaccination [70, 97]. A recent study from Public Health England (PHE) has shown that the vaccine had efficacy against Delta and Alpha variants as $88 \%$ and $93 \%$, respectively, after administration of the second dose [75]. Liu et al. [72] reported that the vaccine had neutralizing activity against the Gamma variant, which is analogous to the action against the Alpha variant, and in the case of the Beta variant, the neutralizing activity was negligible. On the contrary, the vaccine showed two dose-dependent systemic or local reactions, such as grade 1 and 2. A common adverse event was pain at the injection site, and other systematic events were also reported [88, 118]. The common systemic events were fatigue, chills, muscle pain, headache, and joint pain. Fever was also reported in some patients following the first and second dose vaccination but typically resolved within a day [88, 118]. Gladly, no grade 4 adverse events were reported. However, grade 3 reactions such as sleep disturbance and pyrexia have been reported in a few participants $[118,88]$. CDC and FDA reported that the vaccine could cause chest pain and heart inflammation such as myocarditis and pericarditis within a day after receiving the first dose and even after the second dose of vaccination. The incidence rate was about 12.6 cases per million (second doses), which was less severe and usually resolved without medical intervention [10, 16, 49, 150]. In a case-control study conducted in Hong Kong, 16 out of 4,51,939 cases were confirmed with Bell's palsy/ facial nerve palsy after the first dose, whereas another casecontrol study in Israel found no association between Bell's palsy and the vaccine [119, 137].

\section{mRNA-1273}

The mRNA-1273 (Moderna) is an mRNA-based vaccine developed by the National Institutes of Health and Moderna. The vaccine consists of a modified mRNA that 
encodes the spike glycoprotein of SARS-CoV-2 and is manufactured in the form of encapsulated lipid nanoparticles $[33,98]$. More specifically, the vaccine encodes the $\mathrm{S}-2 \mathrm{P}$ antigen, an integral part of the SARS-CoV-2 glycoprotein combined with a trans-membrane anchor and S1S2 cleavage site. The lipid nanoparticle capsule was formulated in an adjustable ratio of mRNA and lipids containing four types of lipids. The vaccine was provided at a concentration of $0.5 \mathrm{mg}$ per milliliter as a sterile liquid for injection (the doses administered), and the dilution was prepared using normal saline [63]. In the phase 1 trial, the vaccine induced both virus-neutralizing antibody and spike glycoprotein binding antibody responses in the participants aged $18-55$ years $[63,98]$. The vaccine (both $25-\mu \mathrm{g}$ and $100-\mu \mathrm{g}$ doses) also elicited CD4 + T-cell responses, predominantly Th1 responses stimulated by S-specific peptide pools with a fraction type 2 helper T-cell (Th2) responses. A minimal level of CD8 + T-cell responses was also reported in the participants vaccinated with $100 \mu \mathrm{g}$ dose (after the second dose) [63].

Based on the interim result from the phase 3 trial, Baden et al. [7] reported that the vaccine had an efficacy of $94.1 \%$ against symptomatic SARS-CoV-2 infection. The efficacy has been found identical across all subgroups aged 18 to $<$ 65 and $\geq 65$ years, comorbidity patients, gender, race, and ethnicity. The vaccine also had an efficacy of $93.6 \%$ in the SARS-CoV-2 seropositive participants [7]. In the Qatar study, the vaccine showed $94.4 \%$ and $100 \%$ efficacy against the Alpha variant at $\geq 28$ days of the first dose and day 14 after the second vaccination dose, respectively. In the case of the Beta variant, the efficacy was $73.7 \%$ and $96.4 \%$ after 28 days of the first dose and 14 days of the second dose, respectively [18]. Conversely, the most common adverse effect was pain at the injection site, and the others were tiredness, headache, muscle ache, joint ache, chills, swollen lymph nodes in the vaccine injected arm, generally resolved within a day or two $[98,131,150]$. Further, nausea, vomiting, and fever were also reported. A significant portion of the participants has experienced these side effects after the second dose [131]. Recently, CDC and FDA have found that the vaccine could cause chest pain and heart inflammation such as myocarditis and pericarditis within a day after receiving the first dose and even after the second dose vaccination. Similar to the BNT162b2 vaccine, the incidence rate of adverse effects of the mRNA-1273 was about 12.6 cases per million dose (second dose) and had less severity and fatality, which did not require any medical intervention $[10,18,49,150]$.

\section{Ad26.COV2.S}

The Janssen Pharmaceuticals Company of Johnson \& Johnson developed the Ad26.COV2.S (adenovirus serotype
26), a replication-defective/non-replicating vaccine, expresses full-length spike glycoprotein of SARS-CoV-2 in host cells after the vaccination [109, 108]. Sadoff et al. [108] reported that the vaccine has CD4 $+\mathrm{T}$ cell $(\mathrm{Th} 1$ and Th2) immune responses specific to spike antigens of SARS-CoV-2 among the participants after the single dose. On day 14, Th1 based CD4 + T-cell responses were detected. The vaccine also induced S-specific (spike antigen) $\mathrm{CD} 8+\mathrm{T}$-cell responses. In addition, neutralizing antibody and spike protein-binding antibody responses were seen in most participants on day 29 after the single dose. These results indicated that the vaccine has immunogenicity in both younger and older adults [108].

The phase 3 ENSEMBLE trial reported that the vaccine had an efficacy of $67 \%$ (single dose) against moderate to severe COVID-19 (symptomatic for at least 14 days) cases and $66 \%$ efficacy against patients having 28 days of onset [109]. The data from the phase 3 ENSEMBLE trial also demonstrated that the vaccine efficacy was $85 \%$ against severe COVID-19 across all region studies and minimized hospitalization and death by COVID-19 after 28 days of vaccination [66]. The effectiveness of the vaccine showed geographical variations such as in the USA, the efficacy was $72 \%$ [128], whereas, in South Africa (95\% cases with the Beta variant), it was $64 \%$ against moderate to severe diseases and $81.7 \%$ against severe or critical illness after 28 days of vaccination. In Brazil $(69 \%$ cases with the Gamma variant), the efficacy was $68.1 \%$ against moderate to severe diseases and $87.6 \%$ against severe or critical illnesses [66]. Conversely, Sadoff et al. reported that the most common local reaction was injection site pain and the most frequent systemic reactions were headache, fatigue, myalgia, and nausea [108].

\section{ChAdOx1 nCoV-19}

The ChAdOx1 nCoV-19 vaccine (chimpanzee adenoviral vector ChAdOx1) also known as AZD1222, is a nonreplicating viral vector vaccine developed by the University of Oxford and pharmaceutical company AstraZeneca. The vaccine contains the surface glycoprotein gene of SARS-CoV-2, which encodes the spike glycoproteins of the virus $[81,98]$. Serum Institute of India manufactured the vaccine by the commercial name of Covishield, and in the EU region, the vaccine is also called Vaxzevria [81, 102]. The vaccine showed both humoral and cellmediated immunity. The vaccine-induced $\mathrm{IgG}$ responses (28 days after vaccination) against the SARS-CoV-2 spike protein in all participants after two-dose vaccination were identical across the ages of $18-55,56-69$, and $\geq 70$ years. Moreover, neutralizing antibody responses have also been found after a booster dose (second dose) and were similar across all age groups. The vaccine also induced T-cell 
responses maximized at day 14 after vaccine administration (first dose) [102].

The interim primary efficacy analysis by Ramasamy et al. [102] revealed that the vaccine's efficacy was $70.4 \%$ after the second dose and $64.1 \%$ after the first dose in all participants $[102,134]$. The USA Phase 3 trial by AstraZeneca revealed that the vaccine had $79 \%$ efficacy among the symptomatic COVID-19 and 100\% efficacy in the severe and hospitalized COVID-19 patients. The efficacy was identical across diverse ethnicity and ages, and showed $80 \%$ efficacy in participants aged $\geq 65$ years [4]. Recent data from Public Health England (PHE) claimed that two doses of the vaccine have an efficacy of $74.5 \%$ against the Alpha and $67.0 \%$ against the Delta variants [75]. Moreover, study data from Canada showed that the vaccine (Vaxzevria) had an efficacy of $90 \%$ against hospitalization or death caused by the Alpha variant, $87 \%$ against the Delta, and $82 \%$ against the Beta and Gamma variants after the first dose. Regarding symptomatic COVID-19 cases, the vaccine was $72 \%$ effective against the Alpha, $70 \%$ against the Delta, and 50\% against the Beta and Gamma variants [5]. On the other hand, both local and systemic reactions were reported in all participants after vaccination. The most common local reaction was pain in the injection site, and other systematic reactions were fever, muscle ache, headache, chills, fatigue, malaise, and nausea, which were primarily mild and had 4-5 days of occurrence after vaccination $[98,102]$. The reactions were more common in younger than older adults ( $\geq 56$ years) [102]. After the first dose, the vaccine also had a rare adverse event called thrombosis (blood clot) with thrombocytopenia syndrome [141].

\section{Gam-COVID-Vac}

Gamaleya National Research Centre for Epidemiology and Microbiology developed a viral vector vaccine to prevent SARS-CoV-2 named Gam-Covid-Vac (Sputnik V). GamCovid-Vac is a combined viral vector vaccine based on recombinant adenovirus type $26(\mathrm{rAd} 26)$ and recombinant adenovirus type 5 (rAd5), which have the gene for SARS$\mathrm{CoV}-2$ full-length spike glycoprotein. After the cell entry, the SARS-CoV-2 full-length spike glycoprotein gene encodes the viral spike glycoproteins rAd26-S and rAd5-S. The vaccine was manufactured in two formulated forms as frozen and lyophilized [74]. It could induce both humoral and cellular immune responses in all participants. The phase 3 clinical trial results revealed that it had induced virus-neutralizing antibody response in the participants aged $\geq 60$ years. Furthermore, the vaccine efficacy was almost similar in the participants aged 18-60 years. Cellmediated immune responses were also identified in the participants where peripheral blood mononuclear cells had secreted IFN- $\gamma$ against SARS-CoV-2 spike glycoprotein (at day 28 after the first dose) [73].

The interim results of the phase 3 trial showed that the vaccine had an efficacy of 91.6\% against COVID-19 (from day 21 after the first dose to the day of receiving the second dose). The preliminary result also showed that the vaccine had $100 \%$ efficacy against severe COVID-19 patients [73]. The Gamaleya National Research Center of Epidemiology and Microbiology, and the Direct Investment Fund claimed that the vaccine produced strong protective neutralizing antibodies against new variants, including Alpha, Beta, Gamma, and Delta (B.1.617.2 and B.1.617.3) [123]. Although, Logunov et al. [74] found no serious adverse events, the most common local reaction was pain at the injection site, and other systematic reactions were headache, asthenia, and muscle and joint pain.

\section{BBIBP-CorV}

The Beijing Institute of Biological Products developed an inactivated vaccine called BBIBP-CorV against SARSCoV-2 to prevent COVID-19 [124, 142]. In phase 2 clinical trial, the immunogenicity of the vaccine was assessed across all participants aged $3-17,18-59$, and $\geq 60$ years by applying a different range of doses such as one-dose $(2 \mu \mathrm{g})$, two-dose $(4 \mu \mathrm{g})$, and three-dose $(8 \mu \mathrm{g})$. The vaccine-induced humoral responses were found as $100 \%$ seroconversion rate in $18-59$ and $\geq 60$ years of participants. In addition, in the 18-59 years group, the seroconversion rate was above $75 \%$ on day 14 after the first dose administration, and the rest of the participants were seroconverted on day 28. The 18-59 years group also had higher neutralizing antibody titers than the $>60$ years group. As the vaccine-induced neutralizing antibodies can neutralize multiple SARS-CoV-2 variants, the vaccine could also provide a cross-protection against the rest of the SARS-CoV-2 variants [147].

Sinopharm reported that the vaccine had an efficacy of $79.34 \%$ in the phase $1 / 2$ trial, and in the phase 3 trial (multi-countries), the efficacy was $79 \%$ in both symptomatic and hospitalized patients after 14 days of vaccination [142]. A recent study has found that it was $78.1 \%$ effective against symptomatic SARS-CoV-2 (adult) $[2,125]$. Contrarily, the vaccine showed both local and systematic reactions. The local reactions were pain at the vaccination site, flush, swelling, scleroma, rash, and itching. The systemic reactions were headache, fever, fatigue, muscle pain, joint ache, cough, breathing difficulty, nausea, diarrhea, and skin itching [110]. 


\section{BBV152}

The Bharat Biotech, Indian Council of Medical Research, and National Institute of Virology, India, developed the BBV152 vaccine. The BBV152 is an inactivated SARS$\mathrm{CoV}-2$ vaccine formulated with alum (Algel-IMDG) containing toll-like receptor (TLR) $[45,46]$. In the phase 1 trial, the vaccine (two doses) induced humoral responses against SARS-CoV-2 at 104 days after vaccination (3 months after the second dose). At the same time, serum neutralizing antibodies were also detected among all the participants. In the phase 2 trial, the vaccine (after two doses) induced prominent Th1 immune responses with a high level of IFN- $\gamma$. The immune responses were significantly higher in the phase 2 trial than in the phase 1 trial. Moreover, the vaccine could induce both memory B-cell and T-cell responses, where the latter expressed the memory phenotype marker CD45RO + . However, cellmediated responses have been reported minimally [45].

Bharat Biotech claimed that the vaccine had an efficacy of $77.8 \%$ against symptomatic, $63.6 \%$ against asymptomatic, and $93.4 \%$ against severe symptomatic COVID-19 cases $[8,44]$. The company also asserted that the vaccine had an efficacy of $65.2 \%$ against the Delta (B.1.617.2) variant and can neutralize the rest of the emerging variants such as the Alpha, Beta, Gamma (P.1- B.1.1.28), Zeta (P.2-B.1.1.28) and Kappa variants $[8,112,113,148,149]$. Contrarily, the most common local adverse reaction was pain at the injection site, followed by other systematic reactions such as headache, fatigue, vomiting, and fever. The reactions were mild to moderate and more frequent after the first dose. However, one severe adverse reaction of viral pneumonitis was reported in the phase 1 trial [45].

\section{Ad5-nCoV}

The CanSino Biologics and the Institute of Biology developed the Ad5-nCoV vaccine (trade name: Convidecia) against SARS-CoV-2 [11]. The Ad5-nCoV vaccine is a non-replicating viral vector vaccine that utilizes the adenovirus type 5 (Ad5) to deliver the SARS-CoV- 2 gene into the human body $[118,154]$. The vaccine had been induced both humoral and cellular responses in most of the participants. The vaccine elicited RBD (receptor binding domain) binding antibodies (four-fold higher) and live virus binding antibodies (four-fold higher) in $94-100 \%$ and $50-75 \%$ of the participants. Moreover, T-cell responses were detected on day 14 after vaccination and antibodies on day 28 , and both were in peaked value at the times mentioned above. The activation of antigen-specific $\mathrm{CD} 4+\mathrm{T}$ cells and CD8 $+\mathrm{T}$ cells was reported in all the participants. However, when pre-existing anti-Ad5 immunity was high, both the antibody and T-cell response were slightly reduced [155].

The Ad5-nCoV vaccine efficacy was $68.83 \%$ (single dose) against all symptomatic and $95.47 \%$ against severe COVID-19 cases 14 days after vaccination. After 28 days of vaccination, the efficacy was $65.28 \%$ against all symptomatic and $90.07 \%$ against severe COVID-19 cases $[11,126]$. Conversely, the vaccine was reported with some common adverse reactions such as fever, fatigue, headache, and muscle ache. Those reactions were mild, moderate, and consistent among all the participants. Further, no severe adverse reactions were noted as a matter of concern [154, 155]. Until 13 August 2021, the phase 3 trial result of the vaccine has not been published yet.

\section{CoronaVac}

CoronaVac (formerly PiCoVacc) is an inactivated SARSCoV-2 vaccine developed and manufactured by Sinovac Life Sciences, a Chinese biotech company $[125,121]$. The CoronaVac vaccine was formulated by propagating SARSCoV-2 (CN02 strain) with kidney cells from African green monkeys, also regarded as WHO Vero $10-87$ cells. Before being manufactured, the vaccine was inactivated by $\beta$ propiolactone and further adsorbed onto aluminum hydroxide [145]. Zhang et al. [152] reported the CoronaVac vaccine had induced humoral responses against SARS-CoV-2 in phase $1 / 2$ trial in the participants aged $18-59$ years $[58,152]$. In addition, the vaccine had a similar immune response in adults aged $\geq 60$ years $[145,152]$. The neutralizing antibody responses were reported in the older ( $\geq 60$ years) and younger adults (18-59 years) with similar magnitude after two doses of vaccination $(3 \mu \mathrm{g}$ and $6 \mu \mathrm{g})[58,145,152]$. The study also reported a strong correlation between the neutralizing antibodies and the anti-RBD $\operatorname{IgG}$ antibodies. Moreover, weak T-cell responses were found in 18-59 years aged adults $[58,152]$.

In Brazil, the phase 3 trial demonstrated that the vaccine efficacy was $51 \%$ against symptomatic and $100 \%$ against severe SARS-CoV-2 infection after the second dose [143]. The study also claimed that the vaccine was $50 \%$ effective against the Gamma variant [128, 143]. In Turkey, the phase 3 trial revealed that the vaccine efficacy was $83.5 \%$ on 14 days after administration of the second dose [121]. Conversely, the most common adverse reactions were mild pain at the injection site, elevated blood pressure, headache, fatigue, dizziness, and rash. There were no grade 4 adverse events or fatality has been seen [121, 145, 152]. However, the case-control study from Hong Kong revealed that the vaccine could cause Bell's palsy, where 28 out of $5,37,205$ cases were confirmed with this type of adverse event [137]. 


\section{ZF2001}

Anhui Zhifei Longcom Biopharmaceutical developed a dimer protein subunit vaccine called ZF2001 [82]. It was formulated by targeting the SARS-CoV-2 spike protein receptor-binding domain (RBD) responsible for the attachment of the virus particle with the human angiotensin-converting enzyme $2[40,120,138,151]$. The vaccine contains RBD-dimer protein which was encoded in Chinese hamster ovary (CHO) cells and conjugated with aluminum hydroxide [151]. It induced humoral responses against SARS-CoV-2 in all participants [151]. In the phase 2 trial, the virus-neutralizing antibodies were found 14 days after the second dose with a seroconversion rate of $76 \%$ in people who received $25 \mu \mathrm{g}$ of vaccine and $72 \%$ in people who received $50 \mu \mathrm{g}$ of the vaccine. However, the third dose of the vaccine was found with an increased seroconversion rate in both $25 \mu \mathrm{g}$ and $50 \mu \mathrm{g}$ dose groups estimating $97 \%$ and $93 \%$, respectively [151].

The efficacy of the vaccine is unknown as of 13 August 2021. The most common adverse reactions were mild and transient pain at the injection site, redness, and swelling, resolved within 3-4 days after vaccination [151].

\section{Sinopharm-Wuhan}

Wuhan Institute of Biological Products (WIBP) developed an inactivated (Vero cell line) SARS-CoV-2 vaccine called Sinopharm-Wuhan to prevent COVID-19 [124, 142]. The vaccine was formulated by culturing the whole SARSCoV-2 with in vitro Vero cell lines and then inactivated twice by using $\beta$-propiolactone under specific conditions and then conjugated with $0.5 \mathrm{mg}$ alum [103]. The Sinopharm-Wuhan vaccine could induce humoral responses against SARS-CoV-2. In phase 1 and 2 trials, the neutralizing antibody responses were reported 14 days after the vaccination (first dose). The trials also documented that the neutralizing antibody responses were higher between 21 and 28 days after the second dose and highest after the third or booster dose administration [146].

Sinopharm reported that the vaccine had an efficacy of $72.51 \%$ [2]. A recent study showed that the vaccine efficacy was $79 \%$ in both symptomatic and hospitalized patients after 14 days of vaccination and $78.1 \%$ against only symptomatic adult patients $[2,142]$. On the contrary, the most common adverse reaction was transient mild pain at the injection site [146].

\section{EpivacCorona}

The Vektor State Research Center of Virology and Biotechnology developed a protein subunit vaccine called EpiVacCorona. The vaccine is based on synthetic peptide antigens of SARS-CoV-2 proteins, conjugated to a carrier protein and adsorbed on aluminum hydroxide (Alum adjuvant) [99].

The efficacy of the vaccine is yet to be known as of 13 August 2021. The second dose of the vaccine reported no adverse events in the participants after vaccination [99].

\section{CoviVac}

The CoviVac is an inactivated coronavirus vaccine developed by the Chumakov Center at the Russian Academy of Sciences. The CoviVac is a two-dose vaccine recommended for 18-60 years aged adults [100]. The details of the vaccine have not been published until 13 August 2021.

\section{Potential COVID-19 vaccines currently at phase 3 trial}

After succeeding in the animal model trial, any vaccine candidate must undergo several human trials, typically known as phases 1, 2, and 3, to get approval. In the phase 3 trial, more volunteers compare to phases 1 , and 2 receive the vaccine to find whether it is effective or not [65]. The main objectives of the phase 3 study are to confirm the safety and efficacy of the vaccines in the medium and long term. Adverse effects and other specific characteristics with factors such as sex and age are also considered in this stage. In the phase 3 trial, the study population needs to observe for a long time, and it should be large and diverse enough to test all safety issues properly [17]. All the studies are conducted on healthy volunteers aged 18 years and older participants. Some organizations are running their vaccine trial in several countries to get more precise outcomes of the vaccine impact. Moreover, other important things related to vaccine development, including adjustment of doses, the time gap between the doses, length of the treatment, and interference with other drugs, are also checked in this phase before the approval [79]. Several potential vaccines from different platforms are currently in phase 3 clinical trial with the involvement of thousands of people around the world illustrated in Table 3 [80].

DNA vaccines are a powerful, promising platform of COVID-19 vaccines for fast and flexible development and production [9]. In the previous outbreak of SARS and MERS, DNA vaccine had induced immune response by producing neutralizing antibody documented in clinical trials, and identical similarities were found between the spike proteins of SARS-CoV-2 and SARS-CoV [42, 55]. At present, ZyCoV-D (developed by Zydus Cadila), AG0302-COVID-19 (AnGes), and INO-4800 (Inovio) are the three DNA vaccines that have been going through in the phase 3 trial. There are also four RNA-based vaccines 


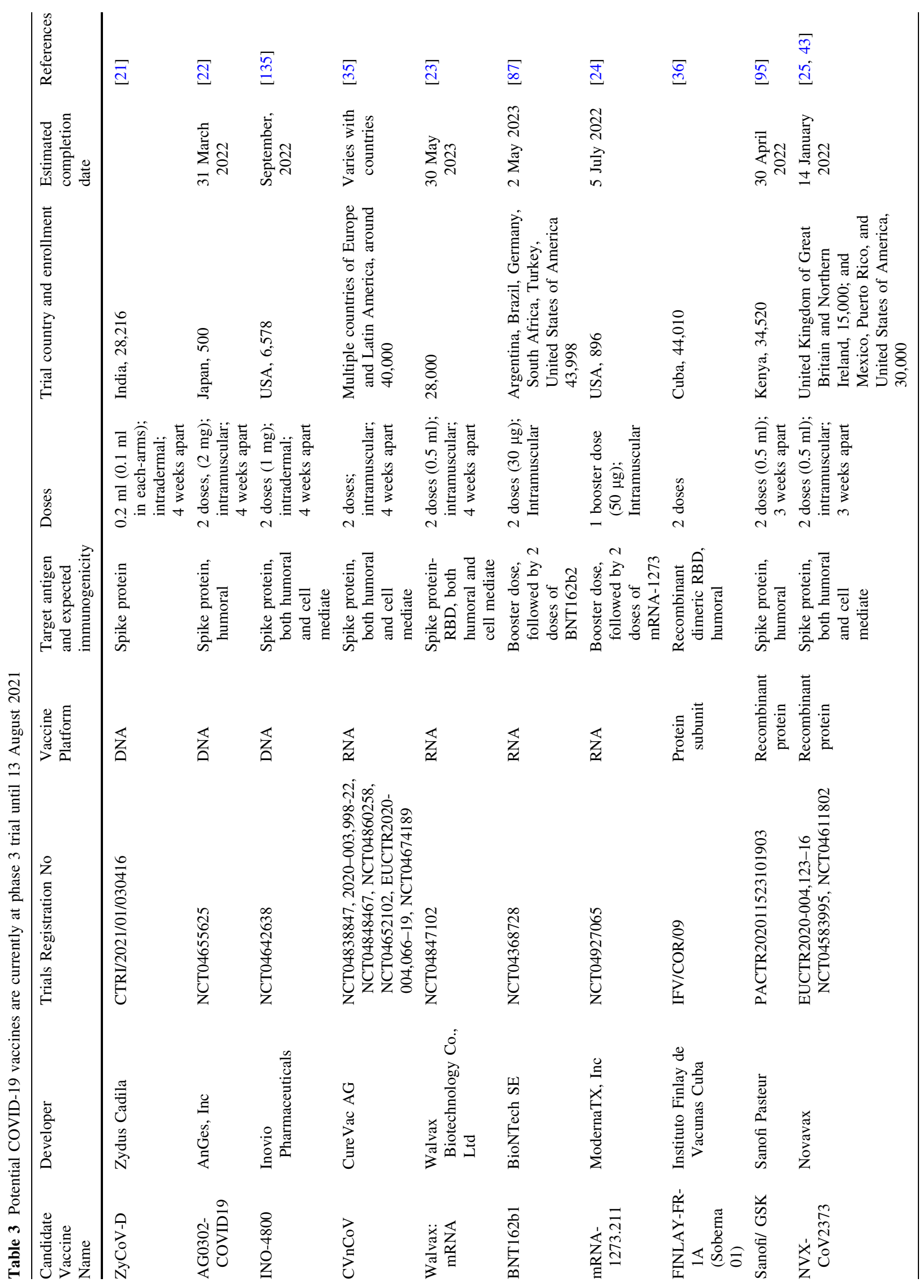




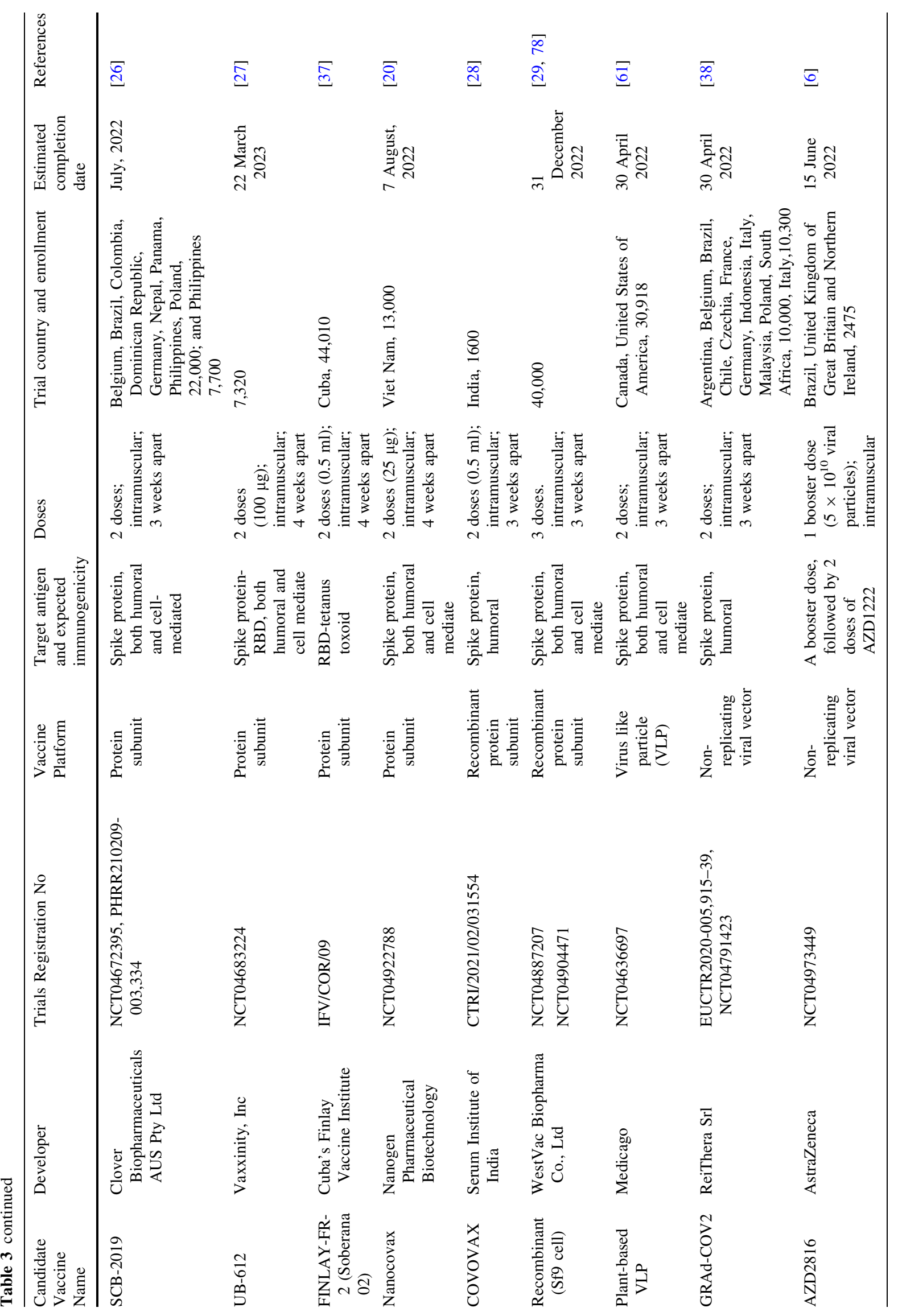




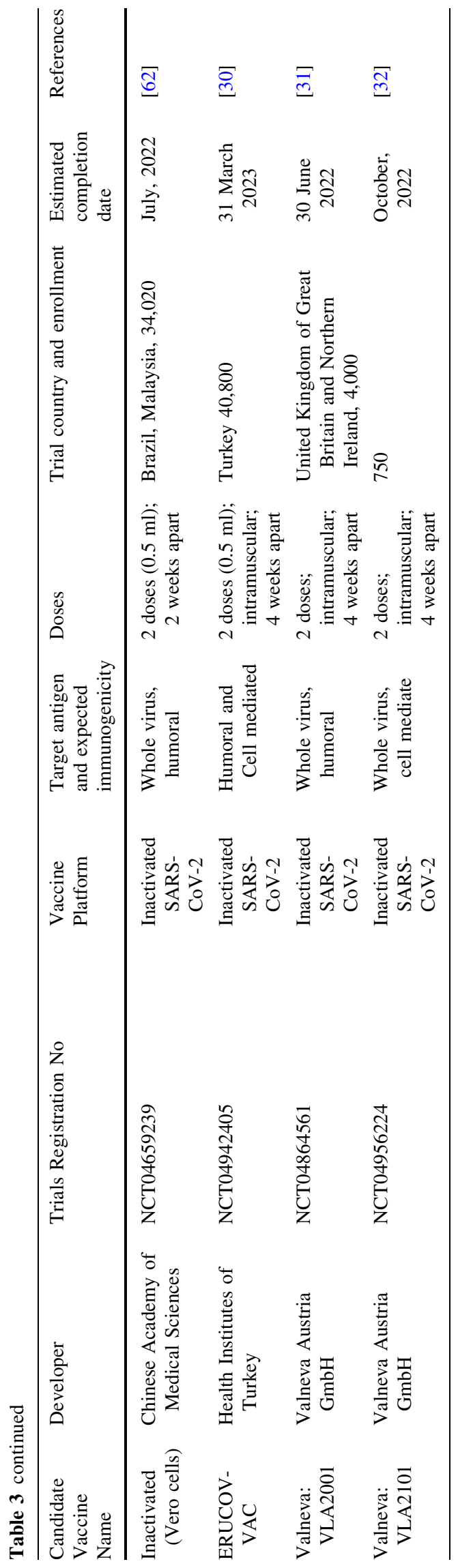

in the race named $\mathrm{CVnCoV}$ (CureVac), Walvax mRNA, BNT162b1, and mRNA-1273.211 [47, 67].

Moreover, in the phase 3 trial list, protein subunit vaccine holds a great place with several candidates, including FINLAY-FR-1)/ Soberna 01 (Finlay Vaccine Institute), Sanofi/ GSK, NVX-CoV2373 (Novavax), SCB-2019 (Clover), UB-612 (COVAXX), FINLAY-FR-2/ Soberna 02 (Instituto Finlay de Vacunas Cuba), Nanocovax, COVOVAX, and Recombinant (Sf9 cell)( West China Hospital) [34].

In addition, virus-like particles (VLP) is another good category of vaccine that induce immune responses with rare adverse effects (during pregnancy or serious sequelae) and develop a polydisperse system [107, 133]. Until 13 August 2021, Plant-based VLP (Medicago) [77] is the only vaccine of this type going through phase 3 trial in Canada and the USA. For producing the VLP, genetically modified Agrobacterium tumefaciens was used to integrate the organism's DNA into a plant cell [133]. In the phase 2 trial of the candidate vaccine, ten times more neutralizing antibodies were found in the vaccinated people than in the recovered COVID-19 patient [93].

Furthermore, GRAd-COV2 (ReiThera) is a non-replicating viral vector vaccine of COVID-19 developed by a biotech company named ReiThera Srl. A novel replicationdefective Gorilla adenovirus encodes full-length prefusion stabilized spike protein of SARS-COV-2 is being used to create this vaccine [104].

Apart from this, Chinese Academy of Medical Sciences: Inactivated (Vero Cells), ERUCOV-VAC, Valneva: VLA2001, and Valneva: VLA2101 vaccines were manufactured using inactivated vaccine-based technology $[34,155]$

\section{Global vaccination coverage to date in combating COVID-19 pandemic}

The first vaccine shot was administered on 14 December 2020 in the USA. As of 14 August 2021, at least 202 countries and regions have started vaccination programs against COVID-19, and more than 4.62 billion vaccines doses have been administered worldwide, which made almost $16 \%$ of the global population vaccinated. ChAdOx1 nCoV-19 vaccine has been distributed in 184 countries, whereas BNT162b2 in 112, mRNA-1273 in 66, BBIBPCorV in 64, Gam-Covid-Vac in 49, CoronaVac in 38, and Ad26.COV2.S in 43 countries until 14 August 2021. Recently approved Sinopharm-Wuhan and Ad5-nCoV administrated in only two countries, whereas BBV152 in 6 countries and EpiVacCorona (Vector Institute) and ZF2001 has been included in vaccination programs of two countries [127]. The Abdala and Soberna 02 have been introduced in 


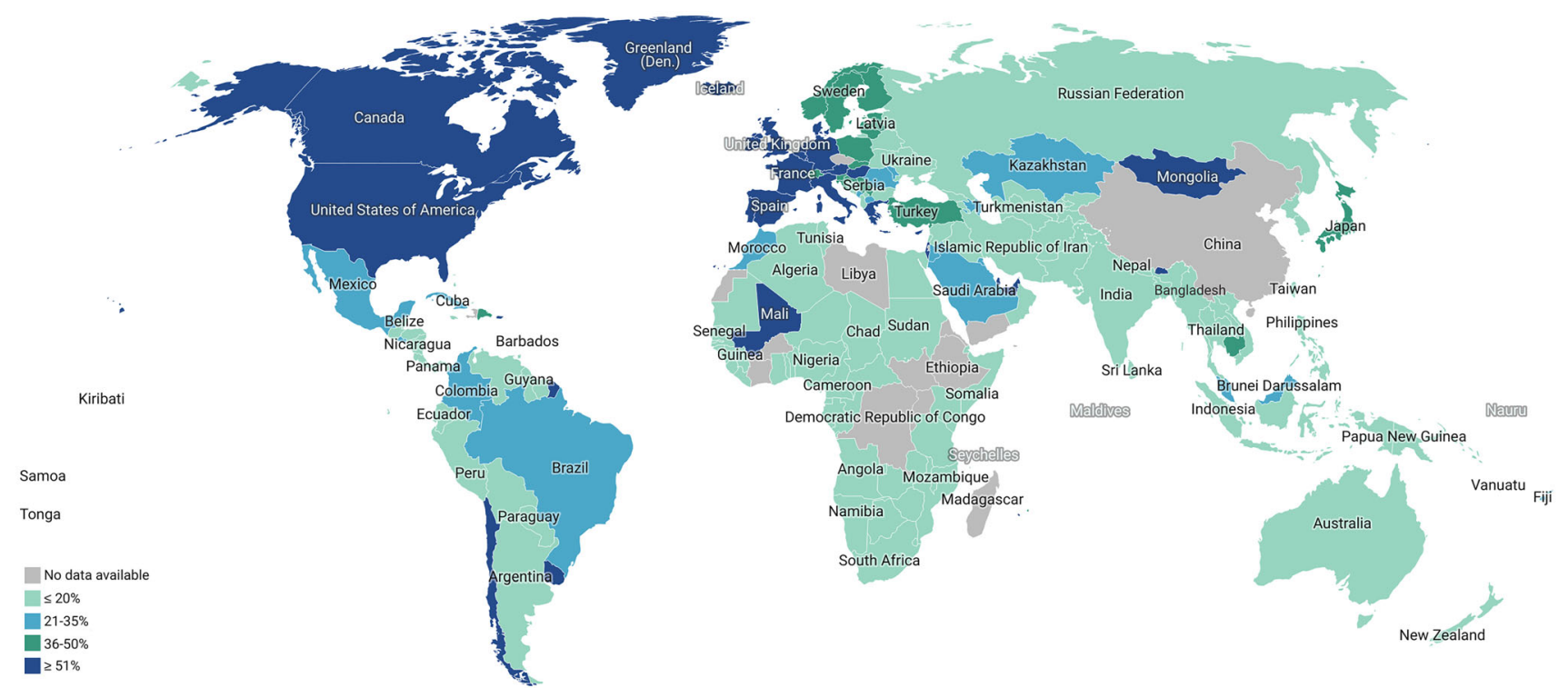

Fig. 3 A comparative overview of global vaccination coverage. People who received complete doses of any vaccines are considered in the figure. This map is created by Datawrapper (https://app. datawrapper.de/select/map) based on the data available at "https://

the vaccination program of Cuba, whereas QazVac and Sinopharm/HayatVax are being used in Kazakhstan and UAE, respectively [127].

Unfortunately, the economic disparity has remarkably influenced the distribution of COVID-19 vaccines worldwide. Low-income countries are not getting the spotlight of the vaccination program as only $0.3 \%$ of the total vaccines are administered in their arms. On the other hand, $83 \%$ of the total shots are applied in the high and upper-middleincome countries to make their people vaccinated [127]. The people of Africa got the lowest doses of vaccines, only 5.8 people per hundred population, whereas 88 people per hundred population brought under vaccination in North America. Furthermore, 91\%, 68\%, 64\%, and $41 \%$ of people become vaccinated in Europe, South America, Asia, and Oceania, respectively (Fig. 3) [127].

Gavi's COVAX Advance Market Commitment (AMC) gave access to COVID-19 vaccines to 92 countries, including low income (such as Afghanistan, Benin, Burkina Faso, Burundi, Central African Republic, Chad, Congo, Ethiopia, and the Gambia) and lower middle income (Algeria, Bangladesh, Bhutan, Bolivia, Cabo Verde, and Cambodia) countries [54]. The list of 92 countries was made based on the Gross National Income (GNI) per capita (under the US \$4,000) with other World Bank's International Development Association (IDA)-eligible economies for maintaining a balanced distribution of vaccines in the world. As of 13 August 2021, more than 196 million COVAX vaccines have been shipped to 138 participants countries [54].
ourworldindata.org/covid-vaccinations?country=OWID_WRL" on 14 August 2021. A total of 4.62 billion doses of vaccines were given to date, and 1.82 billion people worldwide became fully vaccinated

\section{Hopes and challenges}

At this moment, the Delta and Alpha variants of SARSCoV-2 are a matter of discussion worldwide for their profound infectivity [96]. The vaccines we are using now were designed based on the earlier variants of SARS-CoV2, but scientists believe they should still work maybe with less effectiveness. However, studies data suggest that the BNT162b2 vaccine is effective against the new variants, although slightly less efficiently. The efficacy of the ChAdOx $1 \mathrm{nCoV}-19$ vaccine against the Beta variant is not up to the mark but gives sound protection against the Alpha variant. Moreover, the mRNA-1273 vaccine showed more effectiveness against the Beta variant with a weaker and shorter-lived immune response [1].

Furthermore, the discrepancy in the distribution of the COVID-19 vaccines worldwide poses a daunting challenge on the impact of vaccination to control the ongoing pandemic [89]. Most of the wealthy countries pre-ordered vaccine doses, but the low-income countries could not ensure enough amounts, such as the countries of Africa. As of 13 August 2021, 87\% of the total 4.62 billion doses of vaccines are obtained by high-income countries, while lowincome countries just received 0.3 percent. Discrimination is clear as almost one of every four people of rich countries gets vaccinated, while it is one in over 500 in the lowincome countries [132].

More vaccines are getting approval with time, and governments and other organizations should take proper initiatives to produce required vaccine doses. Some issues 
have already arisen, including failure in delivery within the promised date, supply chain breakdown, and substantial global inequality in vaccine access, which is termed "vaccine apartheid" [50]. There are cases like a shortage of vaccines to supply the pre-ordered doses, such as in Bangladesh. The first and second doses of COVID-19 vaccination have been halted as the Serum Institute had failed to provide promised vaccine doses due to the Indian export ban [86]. Conversely, though COVID-19 vaccines are becoming available day by day, different studies reported that many people are in dilemma whether they and their family members should take the vaccines or not. In this era of social media, different kinds of fake news are reported related to the vaccines' safety, and this news is spreading hastily, which is mainly responsible for the vaccine hesitation and anti-vax movement among the people [12].

While the science and healthcare communities are doing their best to halt the spread of COVID-19, some deceitful people and companies are trying to use the pandemic for their benefit by supplying unauthorized and unproven products with fake claims. In China, since August of 2020, a fraud team earned a total of $18 \mathrm{~m}$ yuan $(\$ 2.78 \mathrm{~m}$; $£ 2 \mathrm{~m})$ until 16 February 2021 by selling a fake COVID-19 vaccine, which was a "normal saline" solution or mineral water (https://www.bbc.com/news/world-asia-china56080092). A nurse of a vaccination center in Friesland - a rural district in Germany, injected a saline solution instead of the genuine doses of vaccine (https://www.theguardian. com/world/2021/aug/11/nurse-in-germany-suspected-of-re placing-covid-vaccines-with-saline solution?CMP $=\mathrm{fb} \_g u$ \&utm_medium $=$ Social\&utm_source $=$ Facebook\&fbclid $=$ IwAR3CjWrQNLMoCw2OGcCbodrv2q1RrAo8XN4gD zkesPv_XVf4TUMLabixu-s\#Echobox = 1,628,661, 857).

There was a hope of herd immunity as different studies described that almost $60-70 \%$ of the population gained immunity through vaccinations or past exposure to the virus. But various factors like vaccine hesitancy, the emergence of new variants, and the delayed arrival of vaccinations for children are hampering the process of gaining herd immunity [3].

Ensuring vaccination for children is another challenge as most of the vaccine trials have been done on people above 18 years. But according to CDC, widespread vaccination, including children, is also necessary to halt the pandemic. CDC recommended the BNT162b2 vaccine for children of 12 years or above to protect against COVID-19 [13].

\section{Conclusion}

We are in the midst of the COVID-19 pandemic caused by SARS-CoV-2 that already has taken millions of lives, and if this continues, many more will be lost with inexplicable physical-mental distress and unenumerable financial burdens. The vaccines are the cardinal preventive measures, and others are wearing a mask, maintaining physical distance, and proper sanitation. Globally, people are getting some vaccines that will hopefully contribute to acquiring immunity against SARS-CoV-2, as the initial published results have found promising. The effectiveness and sideeffects of currently available vaccines should be carefully monitored, and the emergence of new variants of SARSCoV-2 must be tracked meticulously. The governments and several other organizations need to work cooperatively to ensure enough and proper production and judicious distribution of the vaccines worldwide.

Authors' contributions All authors have equal contribution.

Data Availability and material Not applicable.

Code availability Not applicable.

\section{Declarations}

Conflict of interest The authors declare that there are no conflicts of interest.

Ethics approval Not applicable.

Consent to participate Not applicable.

Consent for publication Not applicable.

\section{References}

1. Abdulla ZA, Al-Bashir SM, Al-Salih NS, et al. A summary of the SARS-CoV-2 vaccines and technologies available or under development. Pathogens. 2021. https://doi.org/10.3390/patho gens10070788.

2. Al Kaabi N, Zhang Y, Xia S, et al. Effect of 2 Inactivated SARS-CoV-2 vaccines on symptomatic COVID-19 infection in adults: a randomized clinical trial. JAMA. 2021;326:35-45. https://doi.org/10.1001/jama.2021.8565\%JJAMA.

3. Aschwanden C. Five reasons why COVID herd immunity is probably impossible. Nature. 2021;591(7851):520-2. https://doi. org/10.1038/d41586-021-00728-2.

4. AstraZeneca. AZD1222 US Phase III trial met primary efficacy endpoint in preventing COVID-19 at interim analysis. https:// www.astrazeneca.com/media-centre/press-releases/2021/astraze neca-us-vaccine-trial-met-primary-endpoint.html. 2021a. Accessed 13 August 2021.

5. AstraZeneca. Vaxzevria is highly effective after one dose against severe disease or hospitalisation caused by Beta and Delta variants of concern. https://www.astrazeneca.com/mediacentre/press-releases/2021/vaxzevria-is-highly-effective-afterone-dose-against-severe-disease-or-hospitalisation-caused-bybeta-and-delta-variants-of-concern.html. 2021b. Accessed 13 August 2021.

6. Astrazeneca. First COVID-19 variant vaccine AZD2816 Phase II/III trial participants vaccinated. Astrazeneca. https://www. astrazeneca.com/media-centre/press-releases/2021/first-covid- 
19-variant-vaccine-azd2816-phase-ii-iii-trial-participants-vacci nated.html. 2021c. Accessed 13 August 2021.

7. Baden LR, El Sahly HM, Essink B, et al. Efficacy and Safety of the mRNA-1273 SARS-CoV-2 Vaccine. N Engl J Med. 2021;384:403-16. https://doi.org/10.1056/NEJMoa2035389.

8. Bharat Biontech. COVAXIN. https://www.bharatbiotech.com/ covaxin.html. Accessed 13 August 2021.

9. Brisse M, Vrba SM, Kirk N, et al. Emerging concepts and technologies in vaccine development. Front Immunol. 2020;11: 583077. https://doi.org/10.3389/fimmu.2020.583077.

10. CNBC. FDA adds warning about rare heart inflammation to Pfizer, Moderna Covid vaccines. https://www.cnbc.com/2021/ 06/26/fda-adds-warning-of-rare-heart-inflammation-to-pfizer-m oderna-vaccines.html. Accessed 13 August 2021.

11. CanSinoBio. Convidecia - Single shot for faster protection. http://www.cansinotech.com/html/1//156/218/index.html. Accessed 13 August 2021.

12. Carrieri V, Madio L, Principe F. Vaccine hesitancy and (fake) news: Quasi-experimental evidence from Italy. Health Econ. 2019;28:1377-82. https://doi.org/10.1002/hec.3937.

13. Center for Disease Control and Prevention. COVID-19 Vaccines for Children and Teens.https://www.cdc.gov/coronavirus/2019/ ncov/vaccines/recommendations/adolescents.html. 2021d. Accessed 13 August 2021.

14. Center for Disease Control and Prevention. Different COVID-19 Vaccines. https://www.cdc.gov/coronavirus/2019-ncov/vac cines/different-vaccines.html. 2021a. Accessed 13 August 2021.

15. Center for Disease Control and Prevention. Pfizer-BioNTech COVID-19 Vaccine Overview and Safety. https://www.cdc.gov/ coronavirus/2019-ncov/vaccines/different-vaccines/Pfizer-BioN Tech.html. 2021b. Accessed 13 August 2021.

16. Center for Disease Control and Prevention. Myocarditis and Pericarditis Following mRNA COVID-19 Vaccination: National Center for Immunization and Respiratory Diseases (NCIRD), Division of Viral Diseases. https://www.cdc.gov/coronavirus/ 2019-ncov/vaccines/safety/myocarditis.html. 2021c. Accessed 13 August 2021.

17. Chakraborty S, Mallajosyula V, Tato CM, et al. SARS-CoV-2 vaccines in advanced clinical trials: Where do we stand? Adv Drug Deliv Rev. 2021;172:314-38. https://doi.org/10.1016/j. addr.2021.01.014.

18. Chemaitelly H, Yassine HM, Benslimane FM, et al. mRNA1273 COVID-19 vaccine effectiveness against the B.1.1.7 and B.1.351 variants and severe COVID-19 disease in Qatar. Nat Med. 2021;27(9):1614-21. https://doi.org/10.1038/s41591-02101446-y.

19. Chen J, Wang R, Wang M, et al. Mutations strengthened SARSCoV-2 infectivity. J Mol Biol. 2020;432:5212-26. https://doi. org/10.1016/j.jmb.2020.07.009.

20. Clinica Trial. Study to evaluate the safety, immunogenicity, and efficacy of nanocovax vaccine against COVID-19. https://clin icaltrials.gov/ct2/show/NCT04922788. 2021g. Accessed 13 August 2021.

21. Clinical Trials Registry-India. A phase III, randomized, multicentre, double blind, placebo controlled, study to evaluate efficacy, safety and immunogenicity of Novel Corona Virus -2019nCov vaccine candidate of $\mathrm{M} / \mathrm{s}$ Cadila Healthcare Limited. http://ctri.nic.in/Clinicaltrials/showallp.php?mid1= 51254\&EncHid=\&userName=ZyCoV-D. 2021a. Accessed 13 August 2021.

22. Clinical Trial. Phase II / III Study of COVID-19 DNA Vaccine (AG0302-COVID19). https://clinicaltrials.gov/ct2/show/NCT0 4655625. 2021a. Accessed 13 August 2021.

23. Clinical Trial. A Phase III Clinical Study of a SARS-CoV-2 Messenger Ribonucleic Acid (mRNA) Vaccine Candidate Against COVID-19 in Population Aged 18 Years and Above.
https://clinicaltrials.gov/ct2/show/NCT04847102.

$2021 b$.

Accessed 13 August 2021.

24. Clinical Trial. A Study to Evaluate the Immunogenicity and Safety of mRNA-1273.211 Vaccine for COVID-19 Variants. https://clinicaltrials.gov/ct2/show/NCT04927065. 2021c. Accessed 13 August 2021.

25. Clinical Trial. A study looking at the effectiveness, immune response, and safety of a COVID-19 vaccine in adults in the United Kingdom. https://clinicaltrials.gov/ct2/show/NCT0458 3995. 2021d. Accessed 13 August 2021.

26. Clinical Trial. A controlled phase $2 / 3$ study of adjuvanted recombinant SARS-CoV-2 Trimeric S-protein Vaccine (SCB2019) for the prevention of COVID-19 (SCB-2019). https:// clinicaltrials.gov/ct2/show/NCT04672395. 2021e. Accessed 13 August 2021.

27. Clinical Trial. A study to evaluate the safety, immunogenicity, and efficacy of UB-612 COVID-19 vaccine. https://clinicaltrials. gov/ct2/show/NCT04683224. 2021f. Accessed 13 August 2021.

28. Clinical Trials Registry-India. The study to check the safety and immune response of (Covid-19 vaccine) COVOVAX in adults. http://ctri.nic.in/Clinicaltrials/pmaindet2.php?trialid=49327\&E ncHid $=\&$ userName $=$ CTRI $/ 2021 / 02 / 031554$. 2021b. Accessed 13 August 2021.

29. Clinical Trial. A Global Phase III Clinical Trial of Recombinant COVID- 19 Vaccine (Sf9 Cells). https://clinicaltrials.gov/ct2/ show/NCT04887207. 2021h. Accessed 13 August 2021.

30. Clinical Trial. Efficacy, Immunogenicity, and Safety of the Inactivated COVID-19 Vaccine (TURKOVAC) Versus the CoronaVac Vaccine. https://www.clinicaltrials.gov/ct2/show/ NCT04942405. 2021i. Accessed 13 August 2021.

31. Clinical Trial. Study To Compare The Immunogenicity Against COVID-19, Of VLA2001 Vaccine To AZD1222 Vaccine (COV-COMPARE https://clinicaltrials.gov/ct2/show/NCT0486 4561. 2021j. Accessed 13 August 2021.

32. Clinical Trial. Immunogenicity of VLA2101 Compared to VLA2001. https://clinicaltrials.gov/ct2/show/NCT04956224. 2021k. Accessed 13 August 2021.

33. Corbett KS, Flynn B, Foulds KE, et al. Evaluation of the mRNA-1273 Vaccine against SARS-CoV-2 in Nonhuman Primates. N Engl J Med. 2020;383:1544-55. https://doi.org/10. 1056/NEJMoa2024671.

34. Covid-19 Tracker. COVID 19 VACCINE TRACKER. https:// covid19.trackvaccines.org/vaccines/. 2021a. Accessed 13 August 2021

35. Covid-19 Vaccine Tracker. Curevac: CVnCoV. https://covid19. trackvaccines.org/vaccines/11/. 2021b. Accessed 13 August 2021.

36. Covid-19 Vaccine Tracker. Instituto Finlay de Vacunas Cuba: FINLAY-FR-1A. https://covid19.trackvaccines.org/vaccines/ 119/. 2021c. Accessed 13 August 2021.

37. Covid-19 Vaccine Tracker. Instituto Finlay de Vacunas Cuba: FINLAY-FR-2. https://covid19.trackvaccines.org/vaccines/52/. 2021d. Accessed 13 August 2021.

38. Covid-19 Vaccine Tracker. ReiThera: GRAd-COV2. https:// covid19.trackvaccines.org/vaccines/13/. 2021e. Accessed 13 August 2021.

39. Dai L, Gao GF. Viral targets for vaccines against COVID-19. Nat Rev Immunol. 2021;21:73-82. https://doi.org/10.1038/ s41577-020-00480-0.

40. Dai L, Zheng T, Xu K, et al. A universal design of betacoronavirus vaccines against COVID-19, MERS, and SARS. Cell. 2020;182:722-733.e11. https://doi.org/10.1016/j.cell.2020.06. 035.

41. Dan JM, Mateus J, Kato Y, et al. Immunological memory to SARS-CoV-2 assessed for up to 8 months after infection. Science. 2021. https://doi.org/10.1126/science.abf4063. 
42. Dey A, Chozhavel-Rajanathan TM, Chandra H, et al. Immunogenic potential of DNA Vaccine candidate, ZyCoV-D against SARS-CoV-2 in animal models. bioRrxiv. 2021. https:// doi.org/10.1101/2021.01.26.428240.

43. EU Clinical Trials Register. A Phase 3, Randomised, observerblinded, placebo-controlled trial to evaluate the efficacy and safety of a SARS-CoV-2 recombinant spike protein nanoparticle vaccine (SARS-CoV-2 rS) with Matrix-M1 ${ }^{\mathrm{TM}}$ Adjuvant in Adult Participants 18-84 Years of Age in the United Kingdom. https://www.clinicaltrialsregister.eu/ctr-search/trial/2020004123-16/GB. Accessed 13 August 2021.

44. Ella R, Reddy S, Blackwelder W, et al. Efficacy, safety, and lot to lot immunogenicity of an inactivated SARS-CoV-2 vaccine (BBV152): a, double-blind, randomised, controlled phase 3 trial. J medRxiv. 2021. https://doi.org/10.1101/2021.06.30.21259439.

45. Ella R, Reddy S, Jogdand $\mathrm{H}$, et al. Safety and immunogenicity of an inactivated SARS-CoV-2 vaccine, BBV152: interim results from a double-blind, randomised, multicentre, phase 2 trial, and 3-month follow-up of a double-blind, randomised phase 1 trial. Lancet Infect Dis. 2021;21(7):950-61. https://doi. org/10.1016/S1473-3099(21)00070-0.

46. Ella R, Vadrevu KM, Jogdand H, et al. Safety and immunogenicity of an inactivated SARS-CoV-2 vaccine, BBV152: a double-blind, randomised, phase 1 trial. Lancet Infect Dis. 2021;21:637-46. https://doi.org/10.1016/s1473-3099(20)309427.

47. Epstein JH, Anthony SJ, Islam A, et al. Nipah virus dynamics in bats and implications for spillover to humans. Proc Natl Acad Sci U S A. 2020;117(46):29190-201. https://doi.org/10.1073/ pnas. 2000429117.

48. European Medicine Agency. Comirnaty. https://www.ema. europa.eu/en/medicines/human/EPAR/comirnaty. Accessed 13 August 2021.

49. Forbes. CDC Further Investigating Heart Inflammation Cases After Pfizer, Moderna Covid-19 Vaccination. https://www.for bes.com/sites/brucelee/2021/06/13/cdc-further-investigatingheart-inflammation-cases-after-pfizer-moderna-covid-19vaccina tion/?sh=538d80f56853. Accessed 13 August 2021.

50. Forman R, Shah S, Jeurissen P, et al. COVID-19 vaccine challenges: What have we learned so far and what remains to be done? Health Policy. 2021;125:553-67. https://doi.org/10.1016/ j.healthpol.2021.03.013.

51. Forni G, Mantovani A. Covid-19 Commission of Accademia Nazionale dei Lincei R. COVID-19 vaccines: where we stand and challenges ahead. Cell Death Differ. 2021;28:626-39. https://doi.org/10.1038/s41418-020-00720-9.

52. Frederiksen LSF, Zhang Y, Foged C, et al. The long road toward COVID-19 herd immunity: vaccine platform technologies and mass immunization strategies. Front Immunol. 2020;11:1817. https://doi.org/10.3389/fimmu.2020.01817.

53. Funk CD, Laferriere C, Ardakani A. Target product profile analysis of COVID-19 vaccines in phase III clinical trials and beyond: an early 2021 perspective. Viruses. 2021. https://doi. org/10.3390/v13030418.

54. GAVI. 92 low- and middle-income economies eligible to get access to COVID-19 vaccines through Gavi COVAX AMC. https://www.gavi.org/news/media-room/92-low-middle-incomeeconomies-eligible-access-covid-19-vaccines-gavi-covax-amc. 2021d. Accessed 13 August 2021.

55. Gavi. There are four types of COVID-19 vaccines: here's how they work. https://www.gavi.org/vaccineswork/there-are-fourtypes-covid-19-vaccines-heres-how-they-work. 2021a. Accessed 13 August 2021.

56. Gavi. What are viral vector-based vaccines and how could they be used against COVID-19? https://www.gavi.org/vaccines work/what-are-viral-vector-based-vaccines-and-how-could- they-be-used-against-covid-19. 2021b. Accessed 13 August 2021.

57. Gavi. What are protein subunit vaccines and how could they be used against COVID-19?. https://www.gavi.org/vaccineswork/ what-are-protein-subunit-vaccines-and-how-could-they-beused-against-covid-19. 2021c. Accessed 13 August 2021.

58. Hao B, Chen Z, Zeng G, Huang L, Luan C, Xie Z, Chen J, Bao M, Tian X, Xu B, Wang Y, Wu J, Xia S, Yuan L, Huang J. Efficacy, safety and immunogenicity of live attenuated varicella vaccine in healthy children in China: double-blind, randomized, placebo-controlled clinical trial. Clin Microbiol Infect. 2019;25(8):1026-31. https://doi.org/10.1016/j.cmi.2018.12.033.

59. He F, Deng Y, Li W. Coronavirus disease 2019: What we know? J Med Virol. 2020;92:719-25. https://doi.org/10.1002/jmv. 25766.PubMedPMID:32170865.

60. Hemann EA, Kang SM, Legge KL. Protective CD8 T cell-mediated immunity against influenza A virus infection following influenza virus-like particle vaccination. $J$ Immunol. 2013;191:2486-94. https://doi.org/10.4049/jimmunol.1300954.

61. Internatonal Gonference on Harmonization GCP. Study of a Recombinant Coronavirus-Like Particle COVID-19 Vaccine in Adults. https://ichgcp.net/clinical-trials-registry/NCT04636697. 2021a. Accessed 13 August 2021.

62. Internatonal Gonference on Harmonization GCP. The Efficacy, Safety and Immunogenicity Study of Inactivated SARS-CoV-2 Vaccine for Preventing Against COVID-19. https://ichgcp.net/ clinical-trials-registry/NCT04659239. 2021b. Accessed 13 August 2021.

63. Jackson LA, Anderson EJ, Rouphael NG, et al. An mRNA vaccine against SARS-CoV-2: preliminary report. $\mathrm{N}$ Engl J Med. 2020;383:1920-31. https://doi.org/10.1056/NEJMoa2022483.

64. Jeyanathan M, Afkhami S, Smaill F, et al. Immunological considerations for COVID-19 vaccine strategies. Nat Rev Immunol. 2020;20:615-32. https://doi.org/10.1038/s41577-02000434-6.

65. Johnson and Johnson. The 5 Stages of COVID-19 Vaccine Development: What You Need to Know About. https://www.jnj. com/innovation/the-5-stages-of-covid-19-vaccine-developmentwhat-you-need-to-know-about-how-a-clinical-trial-works. Accessed 13 August 2021.

66. Johnson and Johnson. Johnson \& Johnson Single-Shot COVID19 Vaccine Phase 3 Data Published in New England Journal of Medicine. https://www.jnj.com/johnson-johnson-single-shotcovid-19-vaccine-phase-3-data-published-in-new-england-jour nal-of-medicine. Accessed 13 August 2021.

67. Kauffman KJ, Webber MJ, Anderson DG. Materials for nonviral intracellular delivery of messenger RNA therapeutics. J Control Release. 2016;240:227-34. https://doi.org/10.1016/j. jconrel.2015.12.032.

68. Koirala A, Joo YJ, Khatami A, et al. Vaccines for COVID-19: The current state of play. Paediatr Respir Rev. 2020;35:43-9. https://doi.org/10.1016/j.prrv.2020.06.010.

69. Kyriakidis NC, Lopez-Cortes A, Gonzalez EV, et al. SARSCoV-2 vaccines strategies: a comprehensive review of phase 3 candidates. NPJ Vaccines. 2021;6:28. https://doi.org/10.1038/ s41541-021-00292-w.PubMedPMID:33619260;Pub MedCentralPMCID:PMCPMC7900244.

70. Lamb YN. BNT162b2 mRNA COVID-19 vaccine: first approval. Drugs. 2021;81:495-501. https://doi.org/10.1007/ s40265-021-01480-7.

71. Li Y, Tenchov R, Smoot J, et al. A comprehensive review of the global efforts on COVID-19 vaccine development. ACS Cent Sci. 2021;7:512-33. https://doi.org/10.1021/acscentsci.1c00120.

72. Liu Y, Liu J, Xia H, et al.Neutralizing activity of BNT162b2elicited serum. N Engl J Med. 2021;384(15):1466-8. https://doi. org/10.1056/NEJMc2102017. 
73. Logunov DY, Dolzhikova IV, Shcheblyakov DV, et al. Safety and efficacy of an rAd26 and rAd5 vector-based heterologous prime-boost COVID-19 vaccine: an interim analysis of a randomised controlled phase 3 trial in Russia. Lancet (London, England). 2021;397:671-81. https://doi.org/10.1016/s01406736(21)00234-8.

74. Logunov DY, Dolzhikova IV, Zubkova OV, et al. Safety and immunogenicity of an rAd26 and rAd5 vector-based heterologous prime-boost COVID-19 vaccine in two formulations: two open, non-randomised phase 1/2 studies from Russia. Lancet (London, England). 2020;396:887-97. https://doi.org/10.1016/ s0140-6736(20)31866-3.

75. Lopez Bernal J, Andrews N, Gower C, et al. Effectiveness of Covid-19 Vaccines against the B.1.617.2 (Delta). Variant. 2021. https://doi.org/10.1056/NEJMoa2108891.

76. Mahase E. Covid-19: What do we know about the late stage vaccine candidates? BMJ. 2020;371: m4576. https://doi.org/10. 1136/bmj.m4576.

77. Medicago. Leading the way in plant-based vaccine technology. https://www.medicago.com/en/. Accessed 13 August 2021.

78. Meng FY, Gao F, Jia SY, et al. Safety and immunogenicity of a recombinant COVID-19 vaccine (Sf9 cells) in healthy population aged 18 years or older: two single-center, randomised, double-blind, placebo-controlled, phase 1 and phase 2 trials. Signal Transduct Target Ther. 2021;6:271. https://doi.org/10. 1038/s41392-021-00692-3.

79. Miche Bourin. Phase III Clinical trials: what methodology? Symbiosis. https://symbiosisonlinepublishing.com/pharmacypharmaceuticalsciences/pharmacy-pharmaceuticalsciences65. php\#References. Accessed 13 August 2021.

80. Milken Institute. COVID-19 TREATMENT AND VACCINE TRACKER. 2021a. https://covid-19tracker.milkeninstitute.org/ \#vaccine. Accessed 13 August 2021.

81. Milken Institute. Non-Replicating Viral Vector. https://covid19tracker.milkeninstitute.org/\#vaccine_Non-replicating-viralvector. 2021b. Accessed 13 August 2021.

82. Milken Institute. Protein Subunit. https://covid-19tracker.milk eninstitute.org/\#vaccine_Protein-subunit. 2021c. Accessed 13 August 2021.

83. Milken Institute. DNA-Based. https://covid-19tracker.milk eninstitute.org/\#vaccine_DNA-Based. 2021d. Accessed 13 August 2021.

84. Milken Institute. RNA-Based Vaccine. https://covid-19tracker. milkeninstitute.org/\#vaccine_RNA-based-vaccine. 2021e. Accessed 13 August 2021.

85. Milken Institute. Virus-Like Particle. https://covid-19tracker. milkeninstitute.org/\#vaccine_Virus-like-particle. 2021f. Accessed 13 August 2021.

86. Ministry of Health and Family Welfare. First dose halts as India stops supply. http://www.mohfw.gov.bd/index.php. Accessed 13 August 2021.

87. Mulligan MJ, Lyke KE, Kitchin N, et al. Phase I/II study of COVID-19 RNA vaccine BNT162b1 in adults. Nature. 2020;586:589-93. https://doi.org/10.1038/s41586-020-2639-4.

88. Mulligan MJ, Lyke KE, Kitchin N, et al (2020) Phase $1 / 2$ study to describe the safety and immunogenicity of a COVID-19 RNA vaccine candidate (BNT162b1) in Adults 18 to 55 Years of Age Interim Report. medRxiv. doi: https://doi.org/10.1101/2020.06. 30.20142570 .

89. Nature. The COVID vaccine challenges that lie ahead 2020. https://www.nature.com/articles/d41586-020-03334-w. 2021 b. Accessed 13 August 2021.

90. Nature. The race for coronavirus vaccines: a graphical guide. https://www.nature.com/articles/d41586-020-01221-y. $2021 \mathrm{a}$. Accessed 13 August 2021.
91. Ni L, Ye F, Cheng ML, et al. Detection of SARS-CoV-2-specific humoral and cellular immunity in COVID-19 convalescent individuals. Immunity. 2020;52:971-977.e3. https://doi.org/10. 1016/j.immuni.2020.04.023.

92. Oliver SE, Gargano JW, Scobie H, et al. The advisory committee on immunization practices' interim recommendation for use of janssen COVID-19 vaccine - United States, February 2021. MMWR Morb Mortal Wkly Rep. 2021;70:329-32. https:// doi.org/10.15585/mmwr.mm7009e4.

93. PMLIVE. Gsk and medicagos COVID-19 vaccine shows promising antibody responses in phase 2. http://www.pmlive. com/pharma_news/gsk_and_medicagos_COVID-19_vaccine shows_promising_antibody_responses_in_phase_2_1370224. Accessed 13 August 2021.

94. Padron-Regalado E. Vaccines for SARS-CoV-2: lessons from other coronavirus strains. Infect Dis Ther. 2020;23:1-20. https:// doi.org/10.1007/s40121-020-00300-x.

95. Pan African Clinical Trials Registry. Efficacy, Immunogenicity, and Safety of SARS-CoV-2 Recombinant Protein Vaccine with Adjuvant in Adults 18 Years of Age and Older. COVID-19. https://pactr.samrc.ac.za/TrialDisplay.aspx?TrialID=13475. Accessed 13 August 2021.

96. Planas D, Veyer D, Baidaliuk A, et al. Reduced sensitivity of SARS-CoV-2 variant Delta to antibody neutralization. Nature. 2021;596:276-80. https://doi.org/10.1038/s41586-021-03777-9.

97. Polack FP, Thomas SJ, Kitchin N, et al. Safety and efficacy of the BNT162b2 mRNA Covid-19 vaccine. N Engl J Med. 2020;383:2603-15. https://doi.org/10.1056/NEJMoa2034577.

98. Poland GA, Ovsyannikova IG, Kennedy RB. SARS-CoV-2 immunity: review and applications to phase 3 vaccine candidates. Lancet (London, England). 2020;396:1595-606. https:// doi.org/10.1016/s0140-6736(20)32137-1.

99. Precision Vaccinations. EpiVacCorona Vaccine. https://www. precisionvaccinations.com/vaccines/epivaccorona-vaccine. 2021a. Accessed 13 August 2021.

100. Precision Vaccination. CoviVac Russia COVID-19 Vaccine. https://www.precisionvaccinations.com/vaccines/covivac-rus sia-COVID-19-vaccine. 2021b. Accessed 13 August 2021.

101. Rahman MM, Talukdera A, Chowdhury MMH, et al. Coronaviruses in wild birds: a potential and suitable vector for global distribution. Vet Med Sci. 2021;7:264-72. https://doi.org/10. 1002/vms3.360.

102. Ramasamy MN, Minassian AM, Ewer KJ, et al. Safety and immunogenicity of ChAdOx $1 \mathrm{nCoV}-19$ vaccine administered in a prime-boost regimen in young and old adults (COV002): a single-blind, randomised, controlled, phase 2/3 trial. Lancet (London, England). 2021;396:1979-93. https://doi.org/10.1016/ s0140-6736(20)32466-1.

103. Rawat K, Kumari P, Saha L. COVID-19 vaccine: A recent update in pipeline vaccines, their design and development strategies. Eur J Pharmacol. 2021;892: 173751. https://doi.org/ 10.1016/j.ejphar.2020.173751.

104. Reithera. Reithera announces its gra-cov2 COVID-19 vaccine candidate is well tolerated and induces clear immune responses in healthy subjects aged $18-55$ years phase- 1 trial to advance into elderly subjects age. https://reithera.com/2020/11/24/rei thera-announces-its-gra-cov2-COVID-19-vaccine-candidate-iswell-tolerated-and-induces-clear-immune-responses-in-healthysubjects-aged-18-55-years-phase-1-trial-to-advance-intoelderly-subjects-age/. Accessed 13 August 2021.

105. Rey FA, Stiasny K, Vaney MC, et al. The bright and the dark side of human antibody responses to flaviviruses: lessons for vaccine design. EMBO Rep. 2018;19:206-24. https://doi.org/10. 15252/embr.201745302.

106. Rodda LB, Netland J, Shehata L, et al. Functional SARS-CoV2-Specific Immune Memory Persists after Mild COVID-19. 
Cell. 2021;184:169-183.e17. https://doi.org/10.1016/j.cell.2020. 11.029.

107. Roldão A, Mellado MC, Castilho LR, et al. Virus-like particles in vaccine development. Expert Rev Vaccines. 2010;9:1149-76. https://doi.org/10.1586/erv.10.115.

108. Sadoff J, Le Gars M, Shukarev G, et al. Interim results of a phase 1-2a Trial of Ad26.COV2.S covid-19 vaccine. N Engl J Med. 2021;384:1824-35. https://doi.org/10.1056/NEJMoa203 4201.

109. Sadoff J, Gray G, Vandebosch A, et al. Safety and efficacy of single-dose Ad26.COV2.S Vaccine against Covid-19. N Engl J Med. 2021;384(23):2187-201. https://doi.org/10.1056/NEJMoa 2101544

110. Saeed BQ, Al-Shahrabi R, Alhaj SS, Alkokhardi ZM, Adrees AO. Side effects and perceptions following sinopharm COVID19 vaccination. Int J Infect Dis. 2021;111:219-26. https://doi. org/10.1016/j.ijid.2021.08.013.

111. Sahin U, Muik A, Vogler I, et al. BNT162b2 vaccine induces neutralizing antibodies and poly-specific $\mathrm{T}$ cells in humans. Nature. 2021;595(7868):572-7. https://doi.org/10.1038/s41586021-03653-6.

112. Sapkal GN, Yadav PD, Ella R, et al. Neutralization of B.1.1.28 P2 variant with sera of natural SARS-CoV-2 infection and recipients of BBV152 vaccine. J bioRxiv. 2021. https://doi.org/ 10.1101/2021.04.30.441559.

113. Sapkal GN, Yadav PD, Ella R, et al. Inactivated COVID-19 vaccine BBV152/COVAXIN effectively neutralizes recently emerged B.1.1.7 variant of SARS-CoV-2. J Travel Med. 2021. https://doi.org/10.1093/jtm/taab051.

114. Sariol A, Perlman S. Lessons for COVID-19 Immunity from Other Coronavirus Infections. Immunity. 2020;53:248-63. https://doi.org/10.1016/j.immuni.2020.07.005.

115. Schwarzkopf S, Krawczyk A, Knop D, et al. Cellular Immunity in COVID-19 Convalescents with PCR-Confirmed Infection but with Undetectable SARS-CoV-2-Specific IgG. Emerg Infect Dis. 2021. https://doi.org/10.3201/2701.203772.

116. Sewell HF, Agius RM, Kendrick D, et al. Covid-19 vaccines: delivering protective immunity. BMJ (Clinical research ed). 2020;371: m4838. https://doi.org/10.1136/bmj.m4838.

117. Sewell HF, Agius RM, Stewart M, et al. Cellular immune responses to covid-19. BMJ. 2020;370:m3018. https://doi.org/ 10.1136/bmj.m3018.

118. Sharma O, Sultan AA, Ding H, et al. A review of the progress and challenges of developing a vaccine for COVID-19. Front Immunol. 2020;11: 585354. https://doi.org/10.3389/fimmu. 2020.585354.

119. Shemer A, Pras E, Einan-Lifshitz A, et al. Association of COVID-19 vaccination and facial nerve palsy: a case-control study. JAMA Otolaryngol Head Neck Surg. 2021;147:739-43. https://doi.org/10.1001/jamaoto.2021.1259\%JJAMAOtolar yngology-Head\&NeckSurgery.

120. Tai W, He L, Zhang X, et al. Characterization of the receptorbinding domain (RBD) of 2019 novel coronavirus: implication for development of RBD protein as a viral attachment inhibitor and vaccine. Cell Mol Immunol. 2020;17:613-20. https://doi. org/10.1038/s41423-020-0400-4

121. Tanriover MD, Doğanay HL, Akova M, et al. Efficacy and safety of an inactivated whole-virion SARS-CoV-2 vaccine (CoronaVac): interim results of a double-blind, randomised, placebo-controlled, phase 3 trial in Turkey. The Lancet. 2021; 398:213-22. https://doi.org/10.1016/S0140-6736(21)01429-X.

122. The New York Times. Coronavirus Vaccine Tracker. https:// www.nytimes.com/interactive/2020/science/coronavirus-vac cine-tracker.html. 2021a. Accessed 13 August 2021.

123. The Russian Direct Investment Fund. Sputnik V Vaccine Effective Against New Variants of Coronavirus, the Gamaleya
Center Study Published In Vaccines Leading International Journal, SHOWS. https://sputnikvaccine.com/newsroom/press releases/sputnik-v-vaccine-effective-against-new-variants-ofcoronavirus-the-gamaleya-center-study-published. Accessed 13 August 2021.

124. The New York Times. Coronavirus Vaccine Tracker: Leading vaccines. https://www.nytimes.com/interactive/2020/science/ coronavirus-vaccine-tracker.html\#wuhan. 2021i. Accessed 13 August 2021.

125. The New York Times. Coronavirus Vaccine Tracker: Leading vaccines. https://www.nytimes.com/interactive/2020/science/ coronavirus-vaccine-tracker.html\#novavax. 2021j. Accessed 13 August 2021.

126. The New York Times. Coronavirus Vaccine Tracker: Leading vaccines. https://www.nytimes.com/interactive/2020/science/ coronavirus-vaccine-tracker.html\#cansino. 2021k. Accessed 13 August 2021.

127. Times The New York. Tracking Coronavirus Vaccinations Around the World. https://www.nytimes.com/interactive/2021/ world/covid-vaccinations-tracker.html. 20211. Accessed 13 August 2021.

128. Tregoning JS, Flight KE, Higham SL, Wang Z, Pierce BF. Progress of the COVID-19 vaccine effort: viruses, vaccines and variants versus efficacy, effectiveness and escape. Nat Rev Immunol. 2021. https://doi.org/10.1038/s41577-021-00592-1.

129. US Food and Drug Administration. COVID-19 Vaccines. https://www.fda.gov/emergency-preparedness-and-response/cor onavirus-disease-2019-covid-19/covid-19-vaccines. 2021a. Accessed 13 August 2021.

130. US Food and Drug Administration. FDA Approves First COVID-19 Vaccine. https://www.fda.gov/news-events/pressannouncements/fda-approves-first-covid-19-vaccine. 2021b. Accessed 13 August 2021.

131. US Food and Drug Administration. Moderna COVID-19 Vaccine. https://www.fda.gov/emergency-preparedness-and-respons e/coronavirus-disease-2019-covid-19/moderna-covid-19-vac cine. 2021c. Accessed 13 August 2021.

132. United Nations. Low-income countries have received just 0.2 per cent of all COVID-19 shots give. https://news.un.org/en/ story/2021/04/1089392. Accessed 13 August 2021.

133. Uthaya Kumar A, Kadiresen K, Gan WC, et al. Current updates and research on plant-based vaccines for coronavirus disease 2019. Clin Exp Vaccine Res. 2021;10:13-23. https://doi.org/10. 7774/cevr.2021.10.1.13.

134. Voysey M, Clemens SAC, Madhi SA, et al. Safety and efficacy of the ChAdOx1 nCoV-19 vaccine (AZD1222) against SARSCoV-2: an interim analysis of four randomised controlled trials in Brazil, South Africa, and the UK. Lancet (London, England). 2021;397:99-111. https://doi.org/10.1016/s0140-6736(20) 32661-1.

135. WCG Centerwatch. Safety Immunogenicity and Efficacy of INO-4800 for COVID-19 in Healthy Seronegative Adults at High Risk of SARS-CoV-2 Exposure. https://www.centerwatch. $\mathrm{com} /$ clinical-trials/listings/258527/safety-immunogenicity-andefficacy-of-ino-4800-for-COVID-19-in-healthy-seronegativeadults-at-high-risk-of-sars-cov-2-exposure/?\&geo_lat=32. $744774 \&$ geo_lng $=-116.998916 \&$ radius $=10 \& q u e r y=A 11 \% 20 \mathrm{Con}$ ditions\&place=Spring\%20Valley\&user_country=United\%20Sta tes\&rnk=7. Accessed 13 August 2021.

136. Walsh EE, Frenck RW Jr, Falsey AR, et al. Safety and Immunogenicity of Two RNA-Based Covid-19 Vaccine Candidates. N Engl J Med. 2020;383:2439-50. https://doi.org/10. 1056/NEJMoa2027906.

137. Wan EYF, Chui CSL, Lai FTT, et al. Bell's palsy following vaccination with mRNA (BNT162b2) and inactivated (CoronaVac) SARS-CoV-2 vaccines: a case series and nested case- 
control study. Lancet Infect Dis. 2021. https://doi.org/10.1016/ S1473-3099(21)00451-5.

138. Wang Q, Zhang Y, Wu L, et al. Structural and functional basis of SARS-CoV-2 entry by using human ACE2. Cell. 2020;181:894-904.e9. https://doi.org/10.1016/j.cell.2020.03. 045.

139. Word Health Organization. Status of COVID-19 Vaccines within WHO EUL/PQ evaluation process. https://extranet.who. int/pqweb/sites/default/files/documents/Status\%20of\% 20COVID-19\%20Vaccines\%20within\%20WHO\%20EUL-PQ\% 20evaluation \%20process\%20-\%203\%20June\%202021.pdf. 2021e. Accessed 13 August 2021.

140. World Health Organization. Tracking SARS-CoV-2 variants. 2021a. https://www.who.int/en/activities/tracking-SARS-CoV2-variants/. Accessed 13 August 2021.

141. World Health Organization. Global Advisory Committee on Vaccine Safety (GACVS) review of latest evidence of rare adverse blood coagulation events with AstraZeneca COVID-19 Vaccine (Vaxzevria and Covishield). https://www.who.int/news/ item/16-04-2021-global-advisory-committee-on-vaccine-safety(gacvs)-review-of-latest-evidence-of-rare-adverse-blood-coagu lation-events-with-astrazeneca-covid-19-vaccine-(vaxzevriaand-covishield. 2021c. Accessed 13 August 2021.

142. World Health Organization. The Sinopharm COVID-19 vaccine: What you need to know? https://www.who.int/news-room/fea ture-stories/detail/the-sinopharm-covid-19-vaccine-what-youneed-to-know. 2021d. Accessed 13 August 2021.

143. World Health Organization. The Sinovac COVID-19 vaccine: What you need to know. https://www.who.int/news-room/fea ture-stories/detail/the-sinovac-covid-19-vaccine-what-you-needto-know. 2021e. Accessed 13 August 2021.

144. Worldmeter. COVID-19 CORONAVIRUS PANDEMIC. https://www.worldometers.info/coronavirus/\#countries. Accessed 25 August 2021.

145. Wu Z, Hu Y, Xu M, et al. Safety, tolerability, and immunogenicity of an inactivated SARS-CoV-2 vaccine (CoronaVac) in healthy adults aged 60 years and older: a randomised, doubleblind, placebo-controlled, phase 1/2 clinical trial. Lancet Infect Dis. 2021;21:803-12. https://doi.org/10.1016/s1473-3099(20) 30987-7.

146. Xia S, Duan K, Zhang Y, et al. Effect of an inactivated vaccine against SARS-CoV-2 on safety and immunogenicity outcomes: interim analysis of 2 randomized clinical trials. JAMA. 2020;324:951-60. https://doi.org/10.1001/jama.2020.15543.

147. Xia S, Zhang Y, Wang Y, et al. Safety and immunogenicity of an inactivated SARS-CoV-2 vaccine, BBIBP-CorV: a randomised, double-blind, placebo-controlled, phase $1 / 2$ trial. Lancet Infect Dis. 2021;21:39-51. https://doi.org/10.1016/ s1473-3099(20)30831-8.
148. Yadav PD, Sapkal GN, Abraham P, Ella R, et al. Neutralization of variant under investigation B.1.617 with sera of BBV152 vaccinees. Clin Infect Dis. 2021. https://doi.org/10.1093/cid/ ciab411.

149. Yadav PD, Sapkal GN, Ella R, et al. Neutralization against B.1.351 and B.1.617.2 with sera of COVID-19 recovered cases and vaccinees of BBV152. J bioRrxiv. 2021. https://doi.org/10. 1101/2021.06.05.447177.

150. Yale Medicine. Comparing the COVID-19 Vaccines: How Are They Different? https://www.yalemedicine.org/news/covid-19vaccine-comparison. Accessed 13 August 2021.

151. Yang S, Li Y, Dai L, Wang J, et al. Safety and immunogenicity of a recombinant tandem-repeat dimeric RBD-based protein subunit vaccine (ZF2001) against COVID-19 in adults: two randomised, double-blind, placebo-controlled, phase 1 and 2 trials. Lancet Infect Dis. 2021;21(8):1107-19. https://doi.org/10. 1016/S1473-3099(21)00127-4.

152. Zhang Y, Zeng G, Pan H, et al. Safety, tolerability, and immunogenicity of an inactivated SARS-CoV-2 vaccine in healthy adults aged 18-59 years: a randomised, double-blind, placebo-controlled, phase $1 / 2$ clinical trial. Lancet Infect Dis. 2021;21:181-92. https://doi.org/10.1016/s1473-3099(20)308434.

153. Zhao Q, Li S, Yu H, et al. Virus-like particle-based human vaccines: quality assessment based on structural and functional properties. Trends Biotechnol. 2013;31:654-63. https://doi.org/ 10.1016/j.tibtech.2013.09.002.

154. Zhu FC, Guan XH, Li YH, et al. Immunogenicity and safety of a recombinant adenovirus type-5-vectored COVID-19 vaccine in healthy adults aged 18 years or older: a randomised, doubleblind, placebo-controlled, phase 2 trial. Lancet (London, England). 2020;396:479-88. https://doi.org/10.1016/s0140-6736 (20)31605-6.

155. Zhu FC, Li YH, Guan XH, et al. Safety, tolerability, and immunogenicity of a recombinant adenovirus type- 5 vectored COVID-19 vaccine: a dose-escalation, open-label, non-randomised, first-in-human trial. Lancet (London, England). 2020;395:1845-54. https://doi.org/10.1016/s0140-6736(20) 31208-3.

156. Zuo J, Dowell AC, Pearce H, et al. Robust SARS-CoV-2specific $\mathrm{T}$ cell immunity is maintained at 6 months following primary infection. Nat Immunol. 2021;22:620-6. https://doi.org/ 10.1038/s41590-021-00902-8.

Publisher's Note Springer Nature remains neutral with regard to jurisdictional claims in published maps and institutional affiliations. 